\title{
Juzgar en Derecho Constitucional. Bases fundamentales del Derecho Procesal Constitucional en Venezuela
}

Rafael Ortiz-Ortiz*

\begin{abstract}
RESUMEN
El ensayo muestra las bases fundamentales del Derecho Procesal Constitucional como disciplina novedosa en el marco del Derecho Público. Además comprueba que el núcleo esencial del DPC se encuentra en la "pretensión jurídica" que se hace valer, pues ello determina tanto la competencia procesal como el procedimiento; a su vez, la pretensión tiene su fundamento en el "interés jurídico" que el justiciable aspira que sea tutelado. En Venezuela, como es frecuente en América Latina, el control constitucional se difumina en un órgano jurisdiccional exclusivo para el control concentrado, y el control difuso y de tutela de derechos fundamentales confiado, por la Constitución de 1999, a todos los tribunales del país.
\end{abstract}

Palabras clave: Derecho Procesal Constitucional, jurisdicción constitucional, pretensión constitucional, control de la constitucionalidad, tutela constitucional.

\section{Abstract:}

The essay shows the essential bases of constitutional procedural law as a newfangled discipline in the frame of Public Law. Also checks that the essential core of constitutional procedural law is situated in the "legal claim" that is

* Doctor en Derecho por la Universidad Católica Andrés Bello (Caracas), y Doctorando en Ciencias Políticas en la Universidad Central de Venezuela. Magister en Derecho Procesal (UCAB, 2007); Especialista en Derecho Procesal (UCAB, 1994); Especialista en Derecho del Trabajo (UCV, 2001); Especialista en Derecho Administrativo (UCAB, 2002). Ex Magistrado Presidente de la Corte Primera de lo Contencioso Administrativo. Ex Juez Superior en lo Contencioso Administrativo en la Región Central (Caracas), y en la Región Centro Norte (Valencia). Ex Decano de Postgrado en la Universidad Arturo Michelena, fundador de la Especialización en Derecho Constitucional. 
enforced, as this defines the procedural competence as well as the procedure. Also the claim is enforced by the "judicial interest" that is expected to be tutelable by the justiciable. In Venezuela, as it's common in Latin America, the constitutional control blurs into an exclusive jurisdictional organ for concentrated control, and the diffuse control and tutelary of fundamental rights related, by the Constitution of 1999, to every court of the country.

Key words: Constitutional procedural law, constitutional jurisdiction, constitutional claim, constitutional control, constitutional tutelage.

\section{El Derecho Procesal Constitucional}

\subsection{Preliminares}

La más reciente creación de las ciencias jurídicas de nuestro tiempo ha sido encontrar la confluencia teórica y práctica entre la Constitución y el proceso judicial, dando paso a dos disciplinas jurídicas tan apasionantes cuanto se erigen como las herramientas para lograr la "efectiva tutela judicial" y, la salvaguarda y efectividad de los derechos y garantías constitucionales. Nos referimos al "Derecho Constitucional Procesal" y el "Derecho Procesal Constitucional".

En efecto, aquella visión tradicional del Derecho Procesal como complejo de estructuras formales, destinado a resolver jurídicamente los conflictos de intereses entre dos personas, y en los cuales el Juez actuaba siempre como un tercero imparcial sometido a las estrictas pretensiones, alegatos y pruebas de las partes, ha quedado bien atrás. Ciertamente, el "proceso" sigue siendo un "esquema formal", pero su misión y visión ya no se restringe al conflicto jurídicamente trascendente, sino que lo excede hasta elevarse a una categoría superior: los intereses jurídicos. $\mathrm{Y}$ tales intereses pueden ser privados (individuales o colectivos), pero también públicos, y hasta difusos y reaccionales.

En todo proceso existirá, como bien lo dijera el ilustre maestro florentino, Piero Calamandrei, intereses privados y públicos, a veces con preponderancia de uno de ellos, pero necesariamente el Juez debe procurar darle satisfacción; por ello mismo, no es posible concebir un "Derecho Procesal" en estado de "pureza", absolutamente desligado del "interés material" que encuentra respaldo en el "Derecho Sustantivo". En otras ocasiones, es el Derecho Sustantivo quien fija y determina las reglas y principios del Derecho Procesal, sólo hay que mirar aquellos principios y valores del Derecho Sustantivo de niños y adolescentes, y la manera en que éstos determinan la actuación procesal de los sujetos del proceso; miremos también los valores y principios agrarios, para percatarnos que el "Derecho Procesal Agrario" se ve impactado y, a veces, mediatizado por la influencia de aquellos, y así pasaríamos bastante tiempo exhibiendo otros tantos ejemplos.

No ocurre una cosa diferente en el Derecho Sustantivo Constitucional y la manera en que éste se relaciona con el "proceso" y el Derecho Procesal; en muchas 
ocasiones, los principios y valores propiamente constitucionales moldean, fijan y determinan los cometidos y modos en que el proceso se constituye. La preeminencia del fondo sobre las formas (art. 257 CRBV), la primacía de la realidad sobre las formas jurídicas (art. 89 eiusdem), y los contenidos básicos de la efectiva tutela judicial (art. 26) y el debido proceso (art. 49), nos dan cuenta de estas afirmaciones. No es que el "Derecho Procesal Constitucional" sea una manifestación del Derecho Constitucional, de igual modo que el "Derecho Procesal Agrario" no es Derecho Agrario y, en la misma distancia, el "Derecho Procesal Administrativo" no es Derecho Administrativo, pero los contenidos sustanciales de cada una de las ramas sustantivas tiene un enorme peso en la realización de los actos procesales que constituyen el núcleo esencial del Derecho Procesal.

Situándonos entre la "Constitución" y el "proceso", en ninguna otra rama sustantiva esta relación -Derecho Sustantivo y proceso-, es tan estrecha; se produce un matrimonio no por conveniencia sino por necesidad, pues el proceso carecería de su fin "garantístico" sino recibiera de la Constitución el rango y la importancia que se requiere. De igual modo, la Constitución misma requiere de mecanismos y estructuras procesales que tiendan "a darle vida".

Esto lo confirma el hecho de que el juez ya no es un "súbdito procesal" de las partes, esto es absoluta y necesariamente sometido a lo que sea alegado y probado por las partes, y tampoco es un "súbdito de la ley", porque en uno y otro caso, siempre contará con el respaldo de los principios y valores de la Constitución para "enjuiciar" la postulación procesal de las partes, y la postulación jurídica del legislador. Habrá siempre un "juicio de legitimidad constitucional". No se trata de que el juez deba adscribirse a determinada "ética política", ni siquiera debe dar aquiescencia a un determinado "programa constitucional", sino hurgar aquellos valores y principios transhistóricos que no se someten a una mayoría momentánea que aprobó el texto vigente de la Constitución. Como decía Otto Bachoff, el juez no es menos representante del pueblo que los demás poderes del Estado, quizás mucho más, porque la potestad de administrar justicia emana de los ciudadanos, tal como lo postula el artículo 253 de nuestra Constitución.

Por otro lado, la Constitución o el constitucionalismo también ha recibido del Derecho Procesal una influencia fundamental en su propia configuración, al menos en la actividad judicial se han desprendido sus más contundentes instituciones, como lo muestra la sentencia dictada por el Juez Coke en Inglaterra, a principios del siglo XVII, en el caso del "Bonham" sobre la primacía del Derecho natural sobre el common law, y por encima de las prerrogativas del Rey; de igual modo, el famoso fallo Marbury vs Madison, dictado por la Suprema Corte de los Estados Unidos de Norteamérica en 1803, en los cuales el Juez John Marshall justificó la competencia de los jueces para ejercer el control de la constitucionalidad de las leyes del Congreso.

De manera que ese "matrimonio forzado" o necesario ha tenido unos frutos extraordinarios que, este trabajo, no puede profundizar sino mostrar sus nombres. 


\subsection{Definición}

Quizás ha sido una conquista iberoamericana haber elevado a rango constitucional diversas instituciones procesales, que se erigen como "garantías procesales superiores", con la idea de que los procesos judiciales llevan implícitos la necesidad de "verdad" y "justicia" que, por su importancia, se han postulado en la Constitución. Por otro lado, y a la inversa es mucho más claro y contundente, han sido los países iberoamericanos quienes han postulado diversos mecanismos procesales, bajo la idea de que los derechos constitucionales sustantivos no tendrían la misma "eficacia", si no se prevén las "garantías" necesarias para concretar los postulados generales en la esfera concreta de los ciudadanos. Nacen así el "Derecho Constitucional Procesal" y el "Derecho Procesal Constitucional":

Se entiende por Derecho Procesal Constitucional el conjunto de instrumentos jurídicos que establecen los mecanismos específicos de carácter procesal para la efectiva tutela de "intereses jurídico-constitucionales", materializados en la integridad, plenitud y eficacia de la Constitución (contenido objetivo), y la salvaguarda de los derechos u garantías constitucionales (contenido subjetivo).

Procuremos explicar los aspectos más resaltantes de la anterior definición que se ofrece a los solos efectos instrumentales:

i) El Derecho Procesal Constitucional es "el conjunto de instrumentos jurídicos", que van a ser "portadores" de normas, principios, reglas y valores; es decir, no se trata tan sólo de "normas jurídicas" sino que el "conjunto" está informado y conformado por normas, principios, directrices y "valores" atinentes a la "materia" constitucional;

ii) "que establecen los mecanismos específicos de carácter procesal", como resulta de su propio enunciado, el Derecho Procesal son normas, principios y valores destinados o proyectados para un "proceso judicial";

iii) "para la tutela efectiva de intereses jurídico-constitucionales": El elemento nuclear del Derecho Procesal Constitucional es el "interés jurídico" sustantivo que se postula en cada pretensión, entendiendo por interés aquella "necesidad" que tiene un sujeto (individual o colectivamente considerado), y que requieren la tutela en su satisfacción jurídica;

Esta "necesidad" que define el "interés constitucional" puede ser abstractamente considerado, esto es, la necesidad de mantener la "integridad" de la Constitución (P. ej., la pretensión popular de inconstitucionalidad), pero puede descender al campo concreto, en la tutela de necesidades individuales de derechos y garantías propias (pretensión de amparo constitucional, o la pretensión de habeas data).

iv) "materializados en la integridad, plenitud y eficacia de la Constitución (contenido objetivo)": En efecto, esos "elementos procesales" o ese "conjunto" destinados a un proceso judicial tiene como finalidad primaria resguardar el "orden público 
constitucional", o la "integridad constitucional", finalidad que se constituye en su objeto propio;

v) "y la salvaguarda de los derechos u garantías constitucionales (contenido subjetivo)": No basta con reconocer, tácita o implícitamente, un elenco de "derechos sustantivos" en la Constitución, si no se arbitran los mecanismos adecuados para su tutela, defensa o reintegración en caso de ser alterados.

La noción de Derecho Procesal Constitucional no se opone a la justicia constitucional, que incluye mecanismos específicos de tutela, procedimientos especialmente diseñados para la defensa de la Constitución y, como proponía KeLSEN, hasta órganos especializados (Corte Constitucional, Tribunal Constitucional o Sala Constitucional). La problemática está en que, debido a la lozanía y juventud de esta nueva disciplina, todavía la ciencia y los científicos se debaten sobre su naturaleza y contenido, e incluso estamos en fase de elaboración científica la noción de "justicia constitucional” y "jurisdicción constitucional", pues quiérase o no, el estudio netamente "procesal" y "formal" no puede prescindir de la pretensión y el interés "sustantivo" o "material" del Derecho Constitucional. La juventud del Derecho Procesal Constitucional es una interesante aventura en su proceso de maduración, y la necesidad de contar con una "autonomía" al menos científica.

Por otro lado, si el Derecho Procesal Constitucional vincula al "Derecho Procesal" con la Constitución (al servicio y en resguardo de la Constitución), también puede visualizarse un marco de protección constitucional con la tramitación del proceso, es decir, el servicio que presta la Constitución al Derecho Procesal, por lo cual se habla de "Derecho Constitucional Procesal". En efecto, en tiempos recientes viene hablándose, cada día con mayor fuerza, sobre el Derecho Constitucional Procesal, para referirse a la necesaria vinculación que existe entre la Constitución política de un pueblo y la manera en que debe desenvolverse la solución de los conflictos y la tutela, por parte de los órganos jurisdiccionales, de los intereses y derechos de los ciudadanos que acuden ante ellos, poniendo en contacto el derecho de accionar y el deber del Estado de prestar eficientemente el servicio jurisdiccional. Desde luego que, la preocupación que denota la redacción de la Carta Fundamental sobre la finalidad del proceso (tanto administrativo como judicial) y el reconocimiento del Estado de Derecho y de justicia, explica la presencia de disposiciones y principios, de rango constitucional, en todo lo que significa el nacimiento, desarrollo y fin del proceso.

El Derecho Constitucional Procesal alude aquellas categorías procesales específicas que se han elevado a normas constitucionales para reforzar el derecho fundamental de acceso a la jurisdicción (derecho de accionar), y la efectiva tutela judicial, que los jueces deben ofrecer en sus respuestas jurisdiccionales.

i) Se trata de diversas categorías procesales específicas elevadas a normas constitucionales, entre ellos, la constitucionalización del derecho de accionar, derecho 
a la efectiva tutela judicial, garantía del debido proceso, derecho a la defensa, presunción de inocencia, entre otros;

ii) "para reforzar el derecho fundamental de acceso a la jurisdicción", no hay duda que el Derecho Procesal se "sustenta" en el Derecho de accionar, esto es, el derecho público subjetivo que tiene toda persona de acudir ante los órganos jurisdiccionales para invocar la tutela judicial a sus intereses; pues bien, todo el Derecho Procesal supone que "previamente" las personas puedan acudir ante los órganos jurisdiccionales;

iii) "y a la efectiva tutela judicial, que los jueces deben ofrecer en sus respuestas jurisdiccionales", y es que, en efecto, la efectiva tutela judicial a que se contrae el artículo 26 constitucional no es un "deseo", "aspiración" o "programa" constitucional, por el contrario es un clarísimo mandato, imperativo, en cuanto a que los jueces deben dictar la decisión correspondiente en tiempo oportuno, de manera adecuada y, fundamentalmente, una sentencia justa, y eso es lo que significa "efectiva tutela judicial".

El estudio de este aspecto del Derecho Constitucional no puede ni debe pasar desapercibido por los estudiosos de la ciencia procesal, pues tales "garantías" sólo podrán captarse en la medida en que tengan eficacia en el desenvolvimiento de los procesos. No basta con los enunciados generales de acceso a la justicia o efectiva tutela judicial, si no pueden concretarse en instituciones procesales. Así entonces, parte del ámbito propio del Derecho Constitucional Procesal, está algunos principios aplicables al Derecho Procesal en general y algunos específicos para el derecho probatorio, y que pueden extraerse de las normas y principios constitucionales; mientras que otros principios, se coligen de lo establecido en diversos textos legales que regulan los diferentes aspectos procesos. Así por ejemplo, el derecho a un juez natural, imparcial y transparente es aplicable a todo tipo de proceso, pero el derecho de control y contradicción de la prueba, se aplica al derecho probatorio en particular. Por supuesto que ambas categorías enunciadas nos colocan en la interesante discusión si el "Derecho Procesal Constitucional" es una derivación del Derecho Procesal o del Derecho Constitucional; y sobre el "Derecho Constitucional Procesal", es una rama del Derecho Constitucional o es una manifestación del Derecho Procesal.

\section{Fenomenología del Derecho Procesal Constitucional}

Ha señalado el maestro Néstor Pedro Sagüés que, como asignatura joven e impetuosa, el Derecho Procesal Constitucional padece síntomas propios de una crisis de identidad y de crecimiento. Sus contornos no están perfectamente delineados. Su superficie - dice el autor- "puede variar, al menos parcialmente, de autor a autor. Sus engranajes-los procesos constitucionales- difieren de país a país, de tal modo que 
hoy resulta casi indispensable un diccionario de Derecho Procesal Constitucional, para entendernos aunque más no fuere en el escenario latinoamericano"1.

Como dijimos al inicio de este capítulo, la visión tradicional del Derecho Procesal como complejo de estructuras formales, destinado a resolver jurídicamente los conflictos de intereses entre dos personas, y en los cuales el Juez actuaba siempre como un tercero imparcial sometido a las estrictas pretensiones, alegatos y pruebas de las partes, ha quedado bien atrás. Gozainí lo explica muy bien cuando señala que, el Derecho Procesal, clásicamente pensado como mecanismo de resolución para los conflictos entre los hombres, basado en tres órdenes esenciales que atendían el rol del Estado en el proceso (la jurisdicción), el del hombre ante la crisis (la acción) y el sistema de respuesta a esas situaciones de controversia (el proceso), debió responder a nuevas asignaciones responsables; agrega el autor que no era única función la de satisfacer con un proceso las necesidades de la justicia, había que lograr un equilibrio global en el sistema de pesos y contrapesos idealizado por Montesquieu cuando desarrolló el sistema de la trinidad estatal. Es decir, a aquellas funciones del Derecho Procesal debió agregar el control sobre la actividad administrativa (legalidad y razonabilidad de los actos), y el control de la constitucionalidad de las leyes ${ }^{2}$.

Cuando las constituciones -dice más adelante Gozainí- y demás leyes fundamentales de los Estados se analizaron, pronto quedó en evidencia que en ellas había siempre una parte de materia procesal (por ejemplo, la que garantiza un proceso justo; la inviolabilidad de la defensa en juicio; la necesidad del juicio previo a la imposición de una condena; la estabilidad y permanencia de los jueces, etcétera). Por tanto, pudo referirse a un Derecho Constitucional Procesal, en razón del sistema de premisas mayores y menores.

Por otro lado, la internacionalización y preeminencia de los Derechos humanos y la necesidad de garantizar el sistema democrático de gobierno ${ }^{3}$, después de la oscura experiencia de la Segunda Guerra Mundial, fincó la preocupación de los juristas en ofrecer mayor o real efectividad a las declaraciones de Derecho que invadió la conciencia de la civilización occidental, particularmente en América

Vid. SAGÜÉS, Néstor Pedro: Prólogo, a Manili (2005), Pablo Luis (Coord): Derecho Procesal Constitucional. Ed. Universidad. Buenos Aires, 2005, p. 10.

2 Cfr. GOZAINÍ, Osvaldo Alfredo: El Derecho Procesal Constitucional y los derechos humanos (Vínculos y autonomías). Universidad Nacional Autónoma de México. México, 1995, p. 8 y ss.

3 Como dice Álvaro Rodríguez "Democracia constitucional y justicia constitucional son, para la cultura jurídica de nuestro tiempo, realidades de imposible disociación. Muy poco crédito tendría ya el proyecto de edificar una organización estatal democrática, sometida efectivamente al imperio de la Constitución, si ese designio no fuera acompañado de la articulación de un sistema -el que sea- de garantía jurisdiccional de la Constitución misma frente a los actos que puedan atentar a su integridad", en RODRÍGUEZ BEREIJO, Álvaro: "La justicia constitucional en los sistemas contemporáneos", en Anuario Iberoamericano de Justicia Constitucional, $\mathrm{n}^{\circ} 1$, Enero/Diciembre 1997. Centro de Estudios Constitucionales. Madrid, 1997, p. 13 y ss. 
y Europa, es decir, la clara conciencia de que el catálogo de Derechos Humanos, fundamentales o no, no es suficiente para que los ciudadanos encontraran "razón real" de justicia; a la vez, la experiencia del despotismo y abuso de las "mayorías circunstanciales" representada por los Parlamentos, impuso la necesidad de afinar el control, por parte de los órganos jurisdiccionales ordinarios o por un Tribunal especialmente diseñado para ello, de la "juridicidad constitucional" de los actos legislativos.

En estos últimos años se ha expandido (no sólo en espacio sino también en tiempo), una "conciencia constitucional" de los pueblos, lo que supone que la Constitución se erige como una Ley suprema, de democrática observación y acatamiento. Esta conciencia cuando es instrumentalizada y operativizada en la estructura jurídica de los ordenamientos da lugar al "Estado constitucional", lo cual supone, por necesidad, la existencia de una "jurisdicción” y una "justicia” constitucional. El rol de los tribunales constitucionales en las democracias desarrolladas, como en Alemania, España, Italia, Francia, entre otros países, es tan importante para el desarrollo democrático y social, que no se concibe contemporáneamente la existencia de esos Estados democráticos sin una jurisdicción constitucional ${ }^{4}$. Ello se debe a que las cortes constitucionales se han constituido en las entidades garantes de que los demás poderes del Estado respeten la Constitución, y que los ciudadanos cuentan con un "sistema judicial" de protección de sus derechos y garantías constitucionales. En el Estado constitucional el "constitucionalismo" es la limitación jurídica al gobierno; es la antítesis del gobierno autoritario ; y la justicia constitucional es el triunfo de la libertad sobre el poder.

\section{1 "Jurisdicción constitucional" y justicia constitucional}

Excede a nuestro propósito un estudio más detenido sobre "jurisdicción constitucional", y luego en un espectro ampliado, la "justicia constitucional". No es nuestro propósito - pues lo excede en demasía - detenernos como quisiéramos sobre estos aspectos $^{6}$, sólo daremos algunas pinceladas necesarias para facilitar al lector la comprensión de la tutela cautelar en el marco del Derecho Procesal Constitucional.

La llamada "jurisdicción" constitucional no alude a un tipo diferente de "potestad jurisdiccional", y el empleo de la expresión es tan técnicamente incorrecto como

4 Véase en este sentido LANDA ARROYO, César: Tribunal constitucional y Estado democrático. Fondo Editorial de la Pontificia Universidad Católica del Perú. Lima, 1999, p. 29 y ss.

5 Cfr. CAPPELlETTI, Mauro: "Necesidad y legitimidad de la justicia constitucional”, en FAVOREU, LUCHAIRE et. al. Tribunales constitucionales europeos y Derechos humanos. Centro de Estudios Constitucionales. Madrid, 1994, pp. 599-649; POSADA, Adolfo: El régimen constitucional. Librería Suárez. Madrid, 1930, p. 91 y ss.

6 El tema es lo suficientemente importante y extenso que nos ha motivado a realizar un trabajo especial, en fase de elaboración titulado Constitución y proceso. Una introducción al Derecho Procesal Constitucional, que saldrá publicado próximamente. 
hablar de "jurisdicción civil", "mercantil", "agrario" o "penal", es decir, el Derecho Sustantivo aplicable no determina la "naturaleza" de la potestad jurisdiccional, al contrario, la jurisdicción es única e indivisible, pues sea cual sea el área material de conocimiento de los jueces, la potestad jurisdiccional será siempre la misma. Lo que se alude, como suele ocurrir con el abuso de los términos, es una "competencia especial" de un "órgano jurisdiccional específico", lo cual, en el caso que nos ocupa, se vincula con el "control concentrado" de la Constitución.

Sin embargo la expresión "jurisdicción constitucional" ha servido para designar también una dilatada gama de opciones que va desde la expresión "defensa de la Constitución", "control de la constitucionalidad", y hasta la noción de "procesos constitucionales". El término "defensa de la Constitución", fue utilizado copiosamente por Carl Schmitt ${ }^{7}$. Algunos juristas italianos, hablan de giurisdizione costituzionale, entre otros, Mauro Cappelleti ${ }^{8}$, aunque éste también haya utilizado el término de "control" . Otro sector de los doctrinarios italianos se refiere, en cambio, al processo costituzionale ${ }^{10}$. Por su parte, los tratadistas franceses, en su mayoría, hacen referencia al "control de la constitucionalidad", como lo hace Maurice Hauriou ${ }^{11}$ y Léon Duguit" ${ }^{12}$. Los constitucionalistas alemanes utilizan el término "jurisdicción constitucional" (Verfassungsgerichtsbarkeit) ${ }^{13}$, y los angloamericanos el judicial review (revisión judicial) ${ }^{14}$.

\subsubsection{La jurisdicción constitucional como control anulatorio de constitucionalidad}

El maestro mexicano Héctor Fix-Zamudio afirma que los términos "control" de la constitucionalidad y "defensa" de la Constitución, son los de mayor amplitud, ya que "abarcan todo el conjunto de medios que se utilizan para lograr, tanto el funcionamiento armónico y equilibrado de los órganos del poder, como la

SCHMITT, Carl: La defensa de la Constitución (Trad. al. por Manuel Sánchez Sarto). Editorial Labor. Barcelona (España), 1931.

8 Cfr. CAPPELLETTI, Mauro: La jurisdicción constitucional de la libertad (Trad. ital. por Héctor Fix-Zamudio). México, 1961.

9 CAPPELLETTI, Mauro: El control judicial de la constitucionalidad de las leyes en el Derecho comparado (Trad. ital. por Cipriano Gómez Lara y Héctor Fix- Zamudio), UNAM. México, 1966.

10 ABBAmONTE, Giuseppe: Il processo costituzionale italiano. Casa Editrice Dott, Eugenio Jovene. Nápoles, tomo I, 1957.

11 HAURIOU, Maurice: Principes de droit public. Ed. Sirey. París, 1916, p. 31 y ss.

12 DUGUIT, León: Manuel de Droit constitutionnel. Ed. Fontemoing. París, 1918, p. 304 y ss.

13 LECHNER, Hans: Kommentar zum Bundesverfassungsgerichtsgesetz. Ed. Beck. München, 1996.

14 BALBUENA CISNEROS, Arminda: Suprema Corte de Justicia de la Nación y jurisdicción constitucional en México. Tesis Doctoral. Universidad Complutense. Madrid, 2001, p. 20 y ss. 
imposición coactiva de los mandatos fundamentales, en el supuesto de la violación o desconocimiento de la superlegalidad constitucional"15, de tal suerte que la justicia constitucional y la jurisdicción constitucional quedarían incluidas dentro del control y defensa de la Constitución. Por otro lado, José Ángel Marín ha señalado que la justicia constitucional debe ser englobada dentro de la defensa constitucional entendiendo por tal "el conjunto de instituciones y medidas mediante las cuales el Estado resguarda su existencia y ordenamiento frente a los peligros que le amenazan desde dentro... la jurisdicción constitucional [...] tiene por objeto resolver problemas suscitados por la observancia de las normas constitucionales..." ${ }^{16}$.

Sin embargo creemos posible reconducir estas situaciones nominativas a una simplificación didáctica: la jurisdicción constitucional alude a la "competencia" de un órgano específico (Tribunal Constitucional, Corte Constitucional, Sala Constitucional, etc.) para ejercer el "control" de la constitucionalidad de los actos del Poder Público que se dictan en "ejecución directa e inmediata" de la Constitución. En cambio que la noción de "justicia constitucional" tiene relación con un "sistema" de "defensa de la Constitución", que aunque también incluye un control de la constitucionalidad de las leyes pero sólo de manera momentánea y sujeta a la confirmación de la Sala Constitucional de Venezuela.

Afirma el maestro Brewer-Carías que la expresión "Jurisdicción Constitucional" es una noción orgánica, que tiende a identificar a un órgano específico del Poder Judicial que tiene, en forma exclusiva, la potestad de anular ciertos actos estatales por razones de inconstitucionalidad, en particular, las leyes y demás actos con rango de ley o de ejecución directa e inmediata de la Constitución. En los países europeos, dicha Jurisdicción Constitucional corresponde a los Tribunales o Cortes Constitucionales (muchas, incluso, ubicadas fuera del Poder Judicial), al igual que en algunos países latinoamericanos. En cambio, en Venezuela, siempre ha correspondido al Supremo Tribunal de Justicia ${ }^{17}$, ahora a través de su Sala Constitucional. La jurisdicción constitucional enjuicia toda la actividad del Poder Público desde el punto de vista de la Constitución, esto es "asegurar la constitucionalidad de la actividad del poder" ${ }^{18}$.

15 FIX-ZAMUDIO, Héctor: Veinticinco años de evolución de la Justicia Constitucional 19401965. UNAM. México, 1968, p. 13 y ss.

16 Cfr. MARÍN, José Ángel: Naturaleza jurídica del Tribunal Constitucional. Editorial Ariel. Barcelona (España), 1998, p. 14; Cfr. CRUZ VILLALÓN, Pedro: La formación del sistema europeo de control de constitucionalidad (1918-1939). Centro de Estudios Constitucionales. Madrid, 1987, p. 28.

17 Vid. BREWER-CARÍAS, Allan: Judicial Review in Comparative Law. Cambridge; y del mismo autor Instituciones Políticas y Constitucionales, tomo VI, La Justicia Constitucional. Caracas, 1989.

18 Cfr. RUBIO LLORENTE, Francisco: “Tendencias actuales de la Jurisdicción constitucional en Europa”, en RUBIO LLORENTE, Francisco y JIMÉNEZ CAMPO, Javier (eds.): Estudios sobre jurisdicción constitucional. Ed. Mc. Graw Hill, Ciencias Jurídicas. Madrid, 1998, p. 156. 
Hemos empleado la expresión "control anulatorio" porque nos parece mucho más "representativa" de la tarea que desempeña el Tribunal al ejercer la jurisdicción constitucional; en efecto, normalmente se tiende a identificar esta actividad jurisdiccional con el "control concentrado de la constitucionalidad", pero a poco que nos acerquemos a esta noción veremos lo complejo del asunto. El llamado control "concentrado" supone que la "constitucionalidad" de los actos normativos emanados del Poder Público en ejecución directa de competencias constitucionales está "reservado" o "concentrado" en un único tribunal: la Sala Constitucional (Venezuela), Tribunal o Corte Constitucional, en otras latitudes.

Sin embargo, el "control" de la constitucionalidad de las leyes, por ejemplo, puede ser ejercido por todos los tribunales de la República a través del denominado "control difuso de la constitucionalidad" que, si bien es un "control preventivo", provisional y sujeto a confirmación por el respectivo órgano de la jurisdicción constitucional, no por ello se ejercer menos control. De manera que el control constitucional no es exclusivo de la Sala Constitucional, sino que más bien forma parte de la "justicia constitucional". En cambio que, sí resulta absolutamente exclusivo de la jurisdicción constitucional la "potestad anulatoria" de los actos emanados del Poder Público (incluyendo obviamente la leyes que dicta el Parlamento), es un "control" que tiene como finalidad "expulsar" del ordenamiento jurídico aquellas normas (de rango legal) que contrasten con la Constitución. Por ello, el profesor Brewer afirma:

La garantía de la supremacía y efectividad de la Constitución y ser su máximo y último interprete, se insiste, corresponde a todas las Salas del Tribunal Supremo, por igual, por lo que tampoco es correcto señalar como lo hizo la citada sentencia de 17-03-2000, ni siquiera que "en particular" dicha función corresponde a la Sala Constitucional. Esa "particularidad" no deriva de norma alguna de la Constitución. Lo único "particular" que resulta de las competencias judiciales en materia de justicia constitucional, es el monopolio atribuido a la Sala Constitucional para anular ciertos y determinados actos estatales: las leyes y demás actos de rango legal o de ejecución directa e inmediata de la Constitución. Por tanto, ni siquiera la Sala Constitucional tiene el monopolio para ejercer el control concentrado de la constitucionalidad de los actos estatales ${ }^{19}$.

Sólo si entendemos que el "control concentrado" no es potestad anulatoria, la afirmación de Brewer tiene sentido, pues a nuestro ver la Sala Constitucional tiene reservado el "control anulatorio", que el propio autor refiere. Con vista de estas circunstancias ¿Qué debemos entender por “jurisdicción constitucional”?

19 Vid. BREWER-CARÍAS, Allan: El sistema de justicia constitucional en la Constitución de 1999 (Comentarios sobre su desarrollo jurisprudencial y su explicación, a veces errada, en la Exposición de Motivos). Cuadernos de la Cátedra Allan R. Brewer-Carías de Derecho Administrativo, n 13. Universidad Católica Andrés Bello. Caracas, 2000, p. 10 y ss. 
La llamada jurisdicción constitucional alude a aquella competencia específica de un determinado órgano jurisdiccional (Sala Constitucional) por medio del cual se ejerce un "control anulatorio" de aquellos actos dictados por los órganos del Poder Público (nacional, estadal o municipal) que resulten contrarios o contradictorios con los postulados constitucionales.

La jurisdicción constitucional es, entonces, un "control abstracto" sobre la actividad parlamentaria de la República, los estados y los municipios, en la medida en que sólo ellos pueden dictar actos normativos en ejecución directa de la Constitución; de hecho, en sus trabajos Kelsen se refiere a la jurisdicción constitucional como un medio de "control" sobre las competencias del Parlamento, y si bien asoma la idea de que al anular un Ley el Tribunal pudiera fungir como un "legislador negativo", inmediatamente aclara que no se trata de una invasión sobre las competencias del Parlamento ni una afrenta a la "división de poderes" ("división de funciones"), y por ello afirma:

Si quiere mantenerse este principio en la República democrática, de entre sus diferentes significaciones, sólo puede ser tomada en cuenta, razonablemente, aquella que, en lugar de una separación de poderes, indica una división de los mismos, es decir, indica un reparto del poder entre diferentes órganos, no tanto para aislarlos recíprocamente, sino para permitir un control recíproco de los unos sobre los otros. Y ello, no únicamente para impedirles la concentración de un poder excesivo en las manos de un solo órgano -concentración que sería peligrosa para la democracia- sino además, para garantizar la regularidad del funcionamiento de diferentes órganos. Pero, entonces, la institución de la jurisdicción constitucional no está, de ninguna manera, en contradicción con el principio de la separación, sino por el contrario, es una afirmación de éste.

Aclara el autor austríaco que la actividad del Tribunal Constitucional está absolutamente determinada por la Constitución, es decir, su función se asemeja a la de cualquier otro tribunal en general, constituye principalmente aplicación del Derecho, y solamente en una débil medida, creación del derecho: su función es, por tanto, verdaderamente jurisdiccional. Las leyes atacadas de inconstitucionalidad -concluye Kelsen-son las que forman el principal objeto de la jurisdicción constitucional ${ }^{20}$.

20 Las leyes a las que se refiere el autor son aquellos actos emanados de los órganos legislativos, esto es, en las democracias modernas, de los Parlamentos centrales o -tratándose de un Estado Federal- locales. Deben someterse al control de la jurisdicción constitucional todos los actos que acusen forma de leyes, a aún si sólo contienen normas individuales, por ejemplo, el presupuesto. Vid. KELSEN, Hans: La garantía jurisdiccional de la Constitución (La justicia constitucional) (Trad. al. por Rolando Tamayo y Salmorán). Universidad Nacional Autónoma. México, 2001, p. 54 y ss. 


\subsubsection{La justicia constitucional como control y defensa de la Constitución}

Al lado de la expresión "jurisdicción constitucional" la doctrina ha manejado un concepto superior en amplitud: la "justicia constitucional" que no sólo abarca el "control" de la Constitución sino -y fundamentalmente- los derechos y garantías que la Constitución postula para sus ciudadanos. Héctor Fix-Zamudio prefiere utilizar el término de justicia constitucional al de jurisdicción constitucional, ya que considera que este último, "resulta demasiado limitado", pues en estricto sentido "sólo comprende el estudio de la actividad de verdaderos tribunales, formal y materialmente considerados, que conozcan y resuelvan las controversias de naturaleza constitucional de manera específica, es decir que los citados tribunales están especializados en la decisión de los conflictos de carácter constitucional, y aunque la tendencia es creciente hacia la configuración de estos órganos jurisdiccionales especializados, existen numerosos regímenes en los cuales las normas de carácter justicial constitucional se atribuyen a órganos de carácter político, o bien a los jueces ordinarios" ${ }^{21}$, de allí que el autor defina la justicia constitucional:

El conjunto de procedimientos de carácter procesal, por medio de los cuales se encomienda a determinados órganos del Estado, la imposición forzosa de los mandamientos jurídicos supremos, a aquellos otros organismos de carácter público que han desbordado las limitaciones, que para su actividad se establecen en la misma Carta Fundamental.

Por otro lado, Brewer señala que la noción de "justicia constitucional", por tanto, es distinta a la de Jurisdicción Constitucional, pues esta expresión es un concepto material que equivale a control judicial de la constitucionalidad de las leyes y demás actos estatales, el cual ha sido ejercido en nuestro país, siempre, por todos los tribunales pertenecientes a todas las "jurisdicciones", es decir, por todos los órganos que ejercen el Poder Judicial ${ }^{22}$. Hemos estimado que mientras la jurisdicción constitucional es una "competencia específica" de un "tribunal específico", la noción de justicia constitucional alude a un "sistema", es decir, un conjunto de elementos que, debidamente ordenados entre sí, se colocan para un propósito fundamental: la defensa de la constitucionalidad, es decir, la garantía eficaz de la integridad y supremacía de la Constitución, y por ello hemos la hemos definido como sigue:

Se entiende por justicia constitucional el sistema jurídico, orgánicamente estructurado, que tiene como propósito la defensa y garantía de la integridad y supremacía de la Constitución, fundamentalmente en lo que se refiere al goce y ejercicio de los derechos y garantías de los ciudadanos.

21 FIX-ZAMUDIO, Héctor: Veinticinco años de evolución de la Justicia Constitucional 19401965. UNAM. México, 1968, p. 15.

22 Op. cit., p. 11, et passim. 
Decimos que es un "sistema" porque no se trata de un órgano específico, al contrario, la justicia constitucional se encomienda a todos los tribunales del país; tampoco se limita a una competencia específica sino a un "conjunto de procedimientos" destinados a la tutela efectiva de los derechos y garantías de los ciudadanos, lo cual va desde el control difuso de la constitucionalidad de las leyes, hasta el amparo constitucional, pasando por otros mecanismos de tutela constitucional. La noción de justicia constitucional es mucho más amplia porque atañe no sólo al "control de la Constitución", a través del control difuso, sino también la revisión constitucional, interpretación, colisión de leyes, omisión legislativa, conflictos entere ramas del Poder Público, y los recursos específicos de tutela de derechos fundamentales: amparo y habeas data. Por ello estamos de acuerdo con el maestro Brewer-Carías cuando afirma:

En consecuencia, la justicia constitucional, como competencia judicial para velar por la integridad y supremacía de la Constitución, en Venezuela se ejerce por todos los jueces y no sólo por el Tribunal Supremo de Justicia, en cualquier causa o proceso que conozcan y, además, en particular, cuando conozcan de acciones de amparo o de las acciones contencioso administrativas al tener la potestad para anular actos administrativos por contrariedad a la Constitución (como forma de contrariedad al derecho) (art. 259) ${ }^{23}$.

A nuestro ver, la "jurisdicción constitucional" no debe confundirse con las "competencias" de la Sala Constitucional de nuestro Tribunal Supremo de Justicia, ni siquiera cuando tales competencias sean exclusivas; la noción se restringe al llamado "control concentrado", es decir, "control anulatorio" de los actos legislativos del Poder Público; la "justicia constitucional", en cambio, se ejerce por todos los

23 El profesor Brewer advierte que es errada la apreciación que ha hecho la Sala Constitucional en su sentencia $n^{\circ}$ 129/2000, de 17 de marzo, cuando señaló que "la Sala Constitucional tiene atribuida competencia para ejercer la jurisdicción constitucional, es decir, la potestad de juzgar y de hacer ejecutar lo juzgado en materia constitucional". No es posible, en efecto, identificar la Jurisdicción Constitucional con "la potestad de juzgar en materia constitucional" que equivaldría a justicia constitucional. La garantía de la supremacía y efectividad de la Constitución y ser su máximo y último interprete, se insiste, corresponde a todas las Salas del Tribunal Supremo, por igual, por lo que tampoco es correcto señalar como lo hizo la citada sentencia de 17-03-2000, ni siquiera que "en particular" dicha función corresponde a la Sala Constitucional. Esa "particularidad" no deriva de norma alguna de la Constitución. Lo único "particular" que resulta de las competencias judiciales en materia de justicia constitucional, es el monopolio atribuido a la Sala Constitucional para anular ciertos y determinados actos estatales: las leyes y demás actos de rango legal o de ejecución directa e inmediata de la Constitución.

Por tanto, ni siquiera la Sala Constitucional tiene el monopolio para ejercer el control concentrado de la constitucionalidad de los actos estatales. De lo anterior deriva, en definitiva, que no es correcto deducir de la Constitución que la Sala Constitucional tenga la potestad de "juzgar y de hacer ejecutar lo juzgado en materia constitucional" y considerar que eso sea equivalente a la "Jurisdicción Constitucional", pues ello significaría equiparar la justicia constitucional con la Jurisdicción Constitucional. 
tribunales de la República, incluyendo, claro está, a la propia Sala Constitucional. De esta manera, en el procedimiento de amparo constitucional se distribuye la competencia en razón de la competencia material que deriva del derecho o garantía cuya tutela se pide; el procedimiento de habeas data es conocido por los tribunales de municipio; el control difuso por todos los jueces del país, y la revisión, interpretación, conflictos constitucionales, etc., es una competencia ejercida, en exclusiva, por la Sala Constitucional, pero estos aspectos no pertenecen a la jurisdicción constitucional sino a la justicia constitucional.

La noción de justicia constitucional se explica por la preeminencia alcanzada por la noción de "Estado constitucional" que abarca tanto a la jurisdicción constitucional como a la justicia constitucional. Entendemos, siguiendo a Pedro de Vega, que el Estado constitucional, tal como lo entendieron los constituyentes norteamericanos, presenta como estructuras fundamentales dos principios, uno político, que es el "principio democrático" y otro jurídico, que es el de la "supremacía constitucional" 24 .

Como es sabido, el modelo de justicia constitucional construido en Europa tras la Segunda Gran Guerra ha seguido el esquema diseñado por Kelsen que fuera inicialmente plasmado en la Constitución austríaca de 1920: una jurisdicción concentrada en un único Tribunal, separado del resto de los tribunales y llamado a pronunciarse sobre cuestiones estrictamente jurídico-constitucionales, con total abstracción de los conflictos e intereses que subyacen tanto a las normas enjuiciadas como a los concretos casos de aplicación de las mismas. Todo parece indicar que nuestras Cortes Constituyentes quisieron heredar aquella aureola que pretendió asegurar Kelsen cuando concibió a su Corte como "la depositaría de la categoría lógico-fundamental del ordenamiento: es el órgano que confronta norma (abstracta) de la ley con norma (abstracta) de la Constitución para verificar la contradicción lógica eventualmente producida en el seno del ordenamiento".

En definitiva, como afirma Quiroga León el concepto de Justicia Constitucional o, como también se le denomina, Jurisdicción Constitucional surge con el proceso mismo de la constitucionalización del Estado Moderno. Surge cuando el avance del constitucionalismo determina la supremacía de las normas constitucionales por sobre aquella de la legislación ordinaria, cuando para ello se requiere de la defensa -y de su mecanismo- de esa categoría especial de norma positiva determinada en el texto constitucional. En consecuencia, se puede afirmar que la jurisdicción o justicia constitucional surge entre finales del Siglo XVIII y principios del Siglo XIX, luego de la independencia de los Estados Unidos y de la Revolución Francesa,

24 Véase VEGA GARCÍA, Pedro de: La reforma constitucional y la problemática del poder constituyente. Ed. Técnos. Madrid, 1985, p. 86. 
a la par con el especial proceso de constitucionalización que ocurre en Inglaterra a la muerte de Cromwell en $1858^{25}$. En concepto del autor:

Por justicia constitucional, o jurisdicción constitucional, entonces, podemos entender aquel proceso histórico surgido del propio desarrollo constitucional de los Estados Modernos de derecho, que establecieron mecanismos de control, autocontrol y de defensa de la supremacía y vigencia constitucional ${ }^{26}$.

En nuestro ordenamiento jurídico, la "jurisdicción constitucional”, tiene base normativa en una lectura concatenada de los artículos 266.1 y 336 de la Constitución, a saber: "Artículo 266.1. Son atribuciones del Tribunal Supremo de Justicia: 1. Ejercer la jurisdicción constitucional conforme al Título VIII de esta Constitución. (...)". El Título VIII de la Constitución se denomina "De la protección de esta Constitución” y el art. 336 establece, en específico, las atribuciones de la Sala Constitucional, entre otros:

"Artículo 336. Son atribuciones de la Sala Constitucional del Tribunal Supremo de Justicia:

1. Declarar la nulidad total o parcial de las leyes nacionales y demás actos con rango de ley de la Asamblea Nacional, que colida con esta Constitución.

2. Declarar la nulidad total o parcial de las Constituciones y leyes estadales, de las ordenanzas municipales y demás actos de los cuerpos deliberantes de los Estados y Municipios dictados en ejecución directa e inmediata de esta Constitución y que colida con ella.

3. Declarar la nulidad total o parcial de los actos con rango de ley dictados por el ejecutivo Nacional, que colidan con esta Constitución.

4. Declarar la nulidad total o parcial de los actos en ejecución directa e inmediata de esta Constitución, dictados por cualquier otro órgano estatal en ejercicio del Poder Público, cuando colida con ésta; (...).

7. Declarar las omisiones del poder legislativo municipal, estadal o nacional cuando haya dejado de dictar las normas o medidas indispensables para garantizar el cumplimiento de esta Constitución, o las haya dictado en forma incompleta; y establecer el plazo y, de ser necesario, los lineamientos de su corrección".

25 SCHMITT, Carl: La defensa de la Constitución. Ed. Técnos. Madrid, 1983, p. 27 y ss.

26 Vid. QUIROGA LEÓN, Aníbal: "El Derecho Procesal Constitucional y el Código Procesal Constitucional en el Perú", en Revista Jurídica. Facultad de Jurisprudencia y Ciencias Sociales y Políticas. Universidad Católica de Guayaquil, disponible en: http://www.revistajuridicaonline.com/index.php?option $=$ com_content\&task=view\&id $=486 \&$ Itemid $=36 \quad$ [Consultado el 14/07/2011]; del mismo autor: "Una aproximación a la justicia constitucional: el modelo peruano", en AA.VV: Sobre la Jurisdicción Constitucional. Lima: Fondo Editorial Pontificia Universidad Católica del Perú. Lima, 1990, p. 152 y ss. 
Así entonces, el control concentrado de la constitucionalidad, alude a dos criterios básicos no concurrentes: a) el rango legal de los actos dictados por los órganos del Poder Público ${ }^{27}$; y b) la naturaleza del acto, en tanto que éstos sean dictados en ejecución directa o inmediata de la Constitución ${ }^{28}$. Esta competencia constitucional es desarrollada in extenso por el artículo 25 de la LOTSJ:

\section{"Competencia de la Sala Constitucional}

Artículo 25. Es de la competencia de la Sala Constitucional del Tribunal Supremo de Justicia:

1. Declarar la nulidad total o parcial de las leyes nacionales y demás actos con rango de ley de la Asamblea Nacional, que colidan con la Constitución de la República.

2. Declarar la nulidad total o parcial de las Constituciones y leyes estadales, de las ordenanzas municipales y demás actos de los cuerpos deliberantes de los estados y municipios que sean dictados en ejecución directa e inmediata de la Constitución de la República y que colidan con ella.

3. Declarar la nulidad total o parcial de los actos con rango de ley que sean dictados por el Ejecutivo Nacional, que colidan con la Constitución de la República.

4. Declarar la nulidad total o parcial de los actos en ejecución directa e inmediata de la Constitución de la República, dictados por cualquier otro órgano estatal en ejercicio del Poder Público, cuando colidan con aquélla".

La jurisdicción constitucional, en los términos perfilados, es ejercida en exclusiva por la Sala Constitucional del Tribunal Supremo de Justicia, aun cuando la "justicia constitucional" es un "sistema" de protección de la Constitución, que puede ser ejercido por todos los tribunales de cualquier competencia material, nos referimos por ejemplo, el control difuso de la constitucionalidad que puede ejercerlo cualquier tribunal de la República; también la competencia de los tribunales de municipio cuando se trata de pretensiones por habeas data, y el propio procedimiento de amparo constitucional ${ }^{29}$. De allí que la Exposición de Motivos de nuestra Constitución exponga:

27 Compárese las opiniones de FIX ZAMUDIO, Héctor: La influencia de la Constitución en el Derecho procesal mexicano, en VII Congreso Internacional sobre Constitución y Proceso. Universidad de Würzburg, Alemania, 1983.

28 A ello hicimos alusión en nuestro trabajo ORTIZ-ORTIZ, Rafael: Naturaleza y régimen de competencia en la impugnación de las Ordenanzas Municipales, en Libro Homenaje a Gonzalo Pérez Luciani, Tribunal Supremo de Justicia. Caracas, 2000.

29 En igual sentido José Julio Fernández afirma: "Se puede diferenciar entre justicia constitucional y jurisdicción constitucional. La justicia constitucional aludiría a la aplicación judicial de la Constitución (lo que hacen todos los jueces y tribunales) y jurisdicción constitucional se referiría al órgano concentrado que monopoliza la declaración de inconstitucionalidad de las 
La justicia constitucional en Venezuela la ejercen todos los tribunales de la República, no sólo mediante el control difuso de la constitucionalidad, sino además, por otros medios, acciones o recursos previstos en la Constitución y en las leyes, como la acción de amparo constitucional, destinada a ofrecer una tutela judicial reforzada de los derechos humanos reconocidos y garantizados expresa o implícitamente en la Constitución ${ }^{30}$.

\subsection{Orígenes y nomenclatura del Derecho Procesal Constitucional}

Vamos a partir de la conclusión anterior: la jurisdicción constitucional y la justicia constitucional conforman un "conjunto" mayor, el de una disciplina jurídica "especial" y "especializada", fundamentalmente por la "materia" que le toca enjuiciar a los órganos jurisdiccionales a quienes le corresponde la competencia. Esta disciplina nueva, aún en franco proceso de desarrollo, se conoce como "Derecho Procesal Constitucional" (DPC). Aunque para los "procesalistas" no existe duda alguna, muchos autores discuten si el Derecho Procesal Constitucional es una "disciplina autónoma", o si pertenece al Derecho Procesal o al Derecho Constitucional, cuestión sobre la que volveremos más adelante, por ahora vamos a dar alguna noticia sobre la nomenclatura de esta disciplina.

Existe un relativo consenso en que los inicios del DPC se encuentran en Hans KeLSEN, puesto que, como lo refiere García Belaunde, son "sus" tribunales constitucionales los que ponen distancias absolutas con el mecanismo de control de constitucionalidad vigente hasta entonces. La influencia americana en los sistemas de control latinoamericanos no incide para descalificar este punto de partida. Fue Kelsen, afirma el maestro Peruano, quien observó en su justa aplicación las "garantías constitucionales", superando la condición de "garantías individuales" que se precisaba en los derechos subjetivos ${ }^{31}$. Ciertamente Kelsen es el autor del primer

leyes" (Cfr. FERNÁNDEZ RODRÍGUEZ, José Julio: La Justicia constitucional europea ante el siglo XXI. Ed. Técnos. Madrid, 2007, p.16.

30 En nuestro país el profesor Brewer-Carías concluye: "De lo anterior resulta claramente, por tanto, que no es lo mismo "justicia constitucional" que "Jurisdicción Constitucional". La primera corresponde a todos los Tribunales mediante diversos medios judiciales; la segunda está atribuida a un solo órgano judicial que ejerce el control concentrado de la constitucionalidad de las leyes y demás actos con rango legal o dictados en ejecución directa e inmediata de la Constitución y que es la Sala Constitucional del Tribunal Supremo de Justicia. Pero no por ello, como se ha dicho, la Sala tiene el monopolio del control concentrado de la constitucionalidad de todos los actos estatales; lo que tiene es el monopolio de dicho control sólo respecto de determinados actos estatales (los de rango y fuerza de ley y los dictados en ejecución directa e inmediata de la Constitución). Ello es lo que, además, caracteriza la "Jurisdicción Constitucional" en el derecho comparado: la atribución exclusiva a un órgano judicial del poder anulatorio de determinados, y sólo de determinados, actos estatales. Vid. BREWER-CARÍAS, Allan: El sistema de justicia constitucional en la Constitución de 1999, 2000, pp. 18-19.

31 Vid. GARCíA BELAUNDE, Domingo: Derecho Procesal Constitucional. Universidad César Vallejo. Instituto Iberoamericano de Derecho Constitucional. Lima, 1998, p. 12. 
estudio sistemático sobre la jurisdicción constitucional desarrollado en 1928 en su obra "la garantie jurisdictionelle de la Constitution (La justice constitutionnelle)", donde fundamenta y desarrolla en forma sistemática la existencia de una jurisdicción constitucional concentrada y especializada ${ }^{32}$.

Sin embargo, Kelsen no utilizó la expresión "Derecho Procesal Constitucional" sino la de "jurisdicción constitucional” y "justicia constitucional”, y el autor austríaco se refería a un tribunal especialmente diseñado para conocer de la inconstitucionalidad del obrar del Parlamento. En cambio que el DPC, no sólo incluye este aspecto del control jurisdiccional de otra rama del Poder Público, sino también, y fundamentalmente, todos aquellos mecanismos procesales (procedimientos) que tienden a la defensa del bloque constitucional; si se debe adjudicar esa paternidad a Kelsen entonces no podría negarse la existencia del habeas corpus desde el siglo XVI, el amparo constitucional mexicano a mitad del siglo XIX, entre otros aspectos. Por ello el maestro García Belaúnde advierte:

Es indudable que al hablar de jurisdicción constitucional, si bien el nombre es estrecho, nos remitimos, sin querer, al Derecho Procesal Constitucional. Es igual que si hablamos de jurisdicción civil: tarde o temprano terminaremos haciendo Derecho Procesal civil. Lo que sucede es que este paso audaz no lo dio Kelsen, no sólo porque carecía de formación procesal, sino porque la vida lo llevó por otros derroteros, en especial, la teoría del Derecho, temas filosóficos y sociológicos vinculados al Derecho, así como el Derecho internacional público ${ }^{33}$.

Por ello, son muy acertadas las reflexiones del maestro Néstor P. Sagüés quien afirma la existencia de "tres cumpleaños del Derecho Procesal Constitucional" ${ }^{44}$ : el Habeas Corpus Amendment Act Inglesa de 1679, en que se regula con detalle un primer proceso constitucional que garantiza el derecho fundamental a la libertad personal, el de Habeas Corpus; el caso Marbury vs Madison, resuelto por la Corte Suprema Norteamericana el 24 de febrero de 1803, que institucionaliza el sistema judicial de control de constitucionalidad en los Estados Unidos de Norteamérica, aún cuando este no será asumido de inmediato como una práctica sostenida de la Corte Suprema norteamericana, pasando varias décadas, hasta que se asuma efectivamente y realmente en el sistema judicial norteamericano en la segunda mitad del siglo XIX; el tercer antecedente relevante para el Derecho Procesal Constitucional y el cual acelera la reflexión sobre la materia de la jurisdicción constitucional, y un cambio en el paradigma de Estado de derecho, pasando al desarrollo del Estado Constitucional, fue el nacimiento del Tribunal Constitucional como órgano espe-

\section{$32 \quad$ Ibídem.}

33 Vid. GARCÍA BELAUNDE, Domingo: Derecho Procesal Constitucional, 1998, p. 12 y ss.

34 Vid. SAGÜÉS, Néstor Pedro: Derecho Procesal Constitucional. Logros y obstáculos. Ed. Ad Hoc y Konrad Adenauer Stifftung. Buenos Aires, 2006, pp.19-20; en el mismo sentido MANILI, Pablo Luis: "Introducción al Derecho Procesal Constitucional", en MANILI, Pablo Luis: Derecho Procesal Constitucional. Ed. Universidad. Buenos Aires, 2005, p. 25 y ss. 
cializado de control de constitucionalidad en la Constitución de Austria del $1^{\circ}$ de octubre de 1920, en el que juega un rol significativo Hans Kelsen.

Por otro lado, Humberto Nogueira indica que el uso del concepto de Derecho Procesal Constitucional surge en la década del 40 del siglo XX, siendo Niceto Alcalá Zamora y Castillo su creador, en sus obras de exilio en Argentina y México ${ }^{35}$. Sin embargo, el mismo Nogueira debe conceder crédito e importancia que para el desarrollo de nuestra disciplina han tenido Couture, Calamandrei, Cappelletti, y Fix Zamudio en una primera instancia. Eduardo Couture se refiere al Derecho Procesal Constitucional en su trabajo "Las garantías constitucionales del proceso civil", publicado en el libro Estudios de Derecho Procesal en Honor de Hugo Alsina (1978 [1946], pp. 158-173), como asimismo en su obra clásica Fundamentos del Derecho Procesal Civil, cuya primera edición es de 1947, donde dedica la tercera parte del tomo I, a los casos del Derecho Procesal Constitucional. Asimismo, se le considera el padre del Derecho Constitucional Procesal, el cual comprende el estudio de las garantías constitucionales de acceso a la jurisdicción o tutela judicial efectiva y las reglas sustantivas y adjetivas del debido proceso. Piero Calamandrei realiza aportaciones significativas al posterior desarrollo del Derecho Procesal Constitucional al establecer los fundamentos de la jurisdicción constitucional italiana en su obra $\mathrm{La}$ illegittimita constituzionale delle leggi nel processo civile $e^{36}$.

Mauro Cappelletti, por su parte, aportará, en el ámbito de la jurisdicción constitucional, que esta no sólo se refiere al control constitucional orgánico, sino que se amplía con la jurisdicción constitucional protectora de los derechos fundamentales o la jurisdicción constitucional de las libertades lo que precisa en su obra La giurisdizione costituzionale delle liberta, la que será traducida al español por el propio Fix Zamudio como La jurisdicción constitucional de la libertad (con referencia a los

35 Dice Nogueira que el vocablo fue utilizado por primera vez por Niceto Alcalá Zamora y Castillo, exiliado en Argentina, el cual lo utiliza en su libro "Ensayos de Derecho Procesal (civil, penal y constitucional), publicado en Buenos Aires en 1944, reiterándolo en artículo publicado en la Revista de Derecho Procesal, editada en Buenos Aires por Hugo Alsina (año III, 2 Parte, 1945, p.77). Niceto Alcalá Zamora y Castillo que luego emigra a México contratado por la Universidad Nacional Autónoma de México, en su obra Proceso, autocomposición y autodefensa, sostiene que Kelsen constituye el fundador del Derecho Procesal Constitucional. Vid. NOGUEIRA ALCALÁ, Humberto: "Reflexiones sobre el Derecho Procesal Constitucional en América Latina", en Revista de Estudos Constitucionais, Hermenêutica e Teoria do Direito, ${ }^{\circ}$ 2, pp. 127-149 julho-dezembro 2010; Cfr. ALCALÁ-ZAMORA Y CASTILLO, Niceto: Proceso, autocomposición y autodefensa (contribución a los fines del proceso)". UNAM. México, 1991, p. 215.

36 Vid. CALAMANDREI, Piero: Estudios sobre el proceso civil (Trad. ital. por Sentís Melendo). Ed. Jurídica Europa-América. Buenos Aires, 1968, pp. 23-120 y 121-198. El ilustre maestro de Pisa aborda la materia en tres artículos: "Potere Giudiziario e Suprema Corte Costituzionale", "La illegittimita constituzionale delle leggi nel processo civile" y "Corte Costituzionale e autoritá giudiziaria”, publicados en Opere Giudiriche (Calamandrei, 1968, pp. 215-225, 337-412, 609-654). 
ordenamientos alemán, suizo y austriaco $)^{37}$. Además el maestro italiano agrega el necesario estudio del Derecho Procesal trasnacional o jurisdicción constitucional trasnacional, materia que trata también en su artículo "Justicia Constitucional supranacional" ${ }^{38}$.

Es, sin duda, el maestro Héctor Fix Zamudio, discípulo de Alcalá Zamora y Castillo, quién desarrollará y sistematizará el Derecho Procesal Constitucional como disciplina jurídica, cuyo primer trabajo fue su tesis de licenciado en derecho en 1955, denominada "La garantía jurisdiccional de la Constitución mexicana (ensayo de una estructuración procesal del amparo)" (1955), defendida en enero de 1956; publicados dos de sus capítulos en la Revista La Justicia en 19565 y luego el contenido completo en su obra El juicio de Amparo (1964, pp. 5-70). Asimismo, en 1956, publica el artículo "La aportación de Piero Calamandrei al Derecho Procesal Constitucional". Ya en su tesis de licenciatura, Fix Zamudio consideraba la existencia de una disciplina instrumental que se ocupa del estudio de las normas que sirven de medio para la realización de las disposiciones contenidas en los preceptos constitucionales, cuando estos son desconocidos, violados o existe incertidumbre sobre su significado; siendo esta materia una de las ramas más jóvenes de la Ciencia del Derecho Procesal, y por lo tanto, no ha sido objeto todavía de una doctrina sistemática que defina su verdadera naturaleza y establezca sus límites dentro del inmenso campo del Derecho.

Fix Zamudio, en La garantía jurisdiccional de la Constitución mexicana (Ensayo de una estructura procesal del Amparo), se refiere al Derecho Procesal Constitucional como aquél "que se ocupa del examen de las garantías de la propia Ley Fundamental, y que están establecidas en el texto mismo de la norma suprema", y lo conceptualiza como "conjunto armónico y ordenado de actos jurídicos, en vista de la composición de la litis de trascendencia jurídica, que establece una relación de las partes con el juzgador y que se desenvuelve en una serie concatenada de situaciones". No es posible hacer coincidir el Derecho Procesal Constitucional con los "procesos" establecidos en la Constitución porque, de hecho, en nuestro país, la regulación de los diferentes procedimientos que tienden a la "defensa de la Constitución" es obra del legislador ordinario, tal como se evidencia de la Ley Orgánica de Amparo sobre Derechos y Garantías Constitucionales de 1998, y la Ley Orgánica del Tribunal Supremo de Justicia de 2010, que regula en una Disposición transitoria los procedimientos constitucionales más importantes tales como el habeas data, la tutela de intereses suprapersonales, y las reglas procedimentales para atender las diferentes pretensiones jurídico-constitucionales.

37 CAPPELLETTI, Mauro: La jurisdicción constitucional de la libertad (con referencia a los ordenamientos alemán, suizo y austriaco). Instituto de Derecho Comparado. Universidad Nacional Autónoma de México. Imprenta universitaria. México, 1961.

38 CAPPELETTI, Mauro: “Necesidad y legitimidad de la justicia constitucional”, en Tribunales constitucionales europeos y derechos fundamentales. Centro de Estudios Constitucionales. Madrid, 1984, pp. 599-662. 


\subsection{Naturaleza y autonomía del Derecho Procesal Constitucional}

\subsubsection{Autonomía o categoría jurídica}

En otro lugar de esta obra, donde hemos analizado el "Derecho Procesal administrativo", "Derecho Procesal agrario", "Derecho Procesal del trabajo", entre otras, el asunto de la "autonomía" no aparece claramente explicada, pues, en principio, la palabra "autonomía" traduce la idea de que un instituto o individuo "que nadie depende en ciertos conceptos", o que se "basta a sí mismo". Pues bien, difícilmente haya una disciplina jurídica absolutamente "autónoma", pues siempre es necesario cierto grado de dependencia de unas con otras. De manera que, si el DPC es una disciplina "autónoma" o no, nada agrega a su desarrollo, pues en determinados momentos requerirá de los conceptos elaborados por el Derecho Constitucional y, en otros, necesitará de los postulados básicos de la teoría general del proceso.

Desde Aristóteles el mundo de la ciencia y del conocimiento se "organiza" desde las "categorías", esto es, aquellos esquemas mentales en los que, a modo de teoría del conjunto, pueden insertarse determinados "individuos", de forma que toda "especie" es constitutiva de un género mayor con la finalidad de desprender de la categoría elementos que caracterizan a cada uno de sus elementos. Bajo esta visión, la primera categoría en la cual puede insertarse el DPC está en el campo "sustantivo" o en el mundo "adjetivo", y en segundo lugar, si se trata de un instituto de "Derecho material" o de "Derecho formal", lo cual nos dirigirá con mayor precisión sobre su naturaleza "procesal" o "constitucional". En lo que a nosotros respecta, encontramos absoluta claridad en los siguientes aspectos:

i) El DPC, a pesar de enjuiciar el Derecho Sustantivo, es una disciplina "adjetiva", es decir, alude al conjunto de "elementos jurídicos" (normas, reglas, principios y valores) que se dirigen a la tramitación de pretensiones jurídicas procesales;

ii) El DPC forma parte del "Derecho formal" porque si bien conoce de pretensiones jurídicas materiales de carácter "constitucional", no hay duda que toda su normativa jurídica tiende al desenvolvimiento de la acción, jurisdicción y proceso; por último,

iii) El DPC es una disciplina de Derecho público que se desprende del "Derecho Procesal", a pesar de que el contenido, o la sustancia enjuiciada sean "intereses constitucionales", o el llamado "orden público constitucional" a cuya noción nuestro Máximo Tribunal acude frecuentemente en sus decisiones.

Estas pinceladas nos permiten advertir que el DPC es una disciplina de Derecho Procesal a pesar de su innegable vinculación con el Derecho Constitucional de donde toma su materia. Ello así porque nadie puede discutir la "influencia" del Derecho Constitucional en el Derecho Procesal, pero eso no hace que sea una "disciplina constitucional"; esto no es diferente de lo que ocurre en otras materias, por ejemplo, la "materia laboral" o el "Derecho del trabajo" tiene influencia en el "Derecho 
Procesal del trabajo", pero nadie se atrevería a afirmar que esta disciplina forma parte del Derecho del trabajo; lo mismo ocurrirá con el Derecho Procesal agrario, pues nadie discutiría que se trata de una "disciplina procesal" y no un aspecto del Derecho agrario. El maestro González Pérez advierte:

\begin{abstract}
A solución análoga ha de llegarse respecto de Derecho Procesal Constitucional. Partiendo de la unidad fundamental del proceso y utilizando los conceptos propios del Derecho Procesal, ha de estudiarse el conjunto normativo que regula el Tribunal Constitucional y los procesos de que el mismo conoce. (...).

Siendo el Derecho Procesal Constitucional una rama del Derecho Procesal, no ofrecerá distintos problemas la determinación de su naturaleza jurídica que la del Derecho Procesal en general. (...)

Tradicionalmente ha sido considerado el Derecho Procesal como un Derecho de carácter secundario instrumental respecto del derecho material. De aquí que se haya llegado a designar "Derecho adjetivo" o "Derecho formal". Y, concretamente, el Derecho Procesal Constitucional, las normas reguladoras del proceso cuyo objeto son pretensiones fundadas en Derecho Constitucional, se ha considerado como instrumental. Su papel es la defensa de la Constitución ${ }^{39}$.
\end{abstract}

Lo afirmado por el ilustre maestro español tiene perfecta congruencia con la teoría general del proceso a la cual hay que acudir a la hora de sistematizar un procedimiento especial. Desde nuestra óptica, el Derecho Procesal Constitucional constituye un ordenamiento jurídico formal-procesal, de absoluta e innegable naturaleza "procesal" que, debido a la "especificidad", se ve influenciada por una "visión constitucional" como afirma Zagrebelsky ${ }^{40}$, con la misma intensidad que los valores y principios del Derecho administrativo o laboral, impactan al Derecho Procesal administrativo o al Derecho Procesal del trabajo. La sustancia es Derecho Constitucional, pero la forma es de Derecho Procesal, como lo veremos de seguidas.

\title{
2.3.1 La naturaleza "procesal" del DPC
}

Las normas procesales, siempre de carácter "formal", no viene determinado por el Derecho Sustantivo, de manera que las normas reguladoras de los procedimientos constitucionales deben ser estudiadas con independencia de las normas constitucionales sustantivas ${ }^{41}$, sin olvidar los especiales principios y valores que la Constitución

39 Vid. GONZÁLEZ PÉREZ, Jesús: Derecho Procesal Constitucional. Ed. Civitas. Madrid, 1980.

40 Vid. ZAGREBELSKY, Gustavo: ¿Derecho Procesal Constitucional? y otros ensayos de justicia constitucional. Ed. FUNDAP. México, 2004, pp. 17-18;

41 La opinión así se plana y contundente es emitida por ETO CRUZ (1998), Gerardo: "Estudio preliminar", en GARCÍA BELAÚNDE, Domingo: Derecho Procesal Constitucional. Universidad César Vallejo. Instituto Iberoamericano de Derecho Constitucional. Lima, 1998. 
aporta. En sentido contrario, Néstor Pedro Sagüés afirma que el Derecho Procesal Constitucional es de naturaleza "mixta", es decir, que pertenece tanto al Derecho Constitucional como al Derecho Procesal; y siendo que las instituciones procesales se encuentran en la propia Constitución, son los constitucionalistas los que tienen mayor preocupación que los procesalistas ${ }^{42}$.

En nuestra opinión esto es lo mismo que afirmar que los iuslaboralistas están mejor capacitados para aplicar el Derecho Procesal del trabajo; o que los "agraristas" dominan con mayor precisión el Derecho Procesal agrario. No discutimos la influencia que tiene el régimen sustantivo sobre la configuración de los principios y valores a que debe responder el Derecho Procesal, pero desde el punto de vista científico es evidente que el Derecho Procesal Constitucional debe ser mirado bajo la óptica de la teoría integral del proceso. Alessandro Pizzorusso señala que la diferencia entre el Derecho Sustantivo (sea civil, penal, administrativo) y el Derecho Procesal viene dado por la circunstancia de que el primero integra las reglas "sustanciales" para la normación de los diferentes tipos de relaciones, en tanto que el segundo establece el modo mediante el cual obtiene el juez la aplicación coactiva de las normas sustanciales en caso de inobservancia ${ }^{43}$. Como dice Konrad Hesse, el Derecho Constitucional estudia la Constitución, sea en su lectura del texto formal o material o todo lo que ontológicamente se presente como fenómeno constitucional $^{44}$, el Derecho Procesal Constitucional se vincula con los trámites de aquellos procedimientos judiciales que se diseñan para servir de base o instrumento de protección del Derecho Sustantivo constitucional.

En nuestra tradición romanista, si bien el derecho es una unidad y considerado como un todo, se acostumbra desde la época de los romanos a hacer divisiones, algunas muy amplias y otras más ceñidas. Una de ellas es la existente entre el Derecho Sustantivo y el derecho instrumental, que precisamente sirve para hacer efectivos los derechos que aquél consagra. Este derecho instrumental es el comúnmente llamado Derecho Procesal, que, nacido científicamente en el siglo pasado, se ha extendido y afianzado durante el presente siglo. Y por cierto, esto no ha pasado desapercibido a los estudiosos. Es por eso que hay muchos que desde los años cuarenta (en el mundo hispano, Niceto Alcalá-Zamora y Castillo) han propuesto la creación de una nueva disciplina que se titule Derecho Procesal Constitucional, que sería el equivalente, en el ámbito constitucional, de lo que es el proceso civil para el derecho civil, o el proceso penal para el ámbito del Derecho Penal. Por cierto, esta

42 Vid. SAGÜÉS, Néstor Pedro: Derecho Procesal Constitucional, T.1, Recurso extraordinario. Ed. Astrea. Buenos Aires, 1998.

43 Vid. PIZZORUSSO, Alessandro: Lecciones de Derecho constitucional. Centro de Estudios Constitucionales. Madrid, 1984, vol. I, pp. 10-11.

44 Vid. HESSE, Konrad: Escritos de Derecho constitucional. Centro de Estudios Constitucionales. Madrid, 1992, pp. 3 y ss; Cfr. HAURIOU, Maurice: Derecho constitucional e instituciones políticas. Ed. Ariel. Barcelona (España), 1980. 
tesis no es pacífica, pues en torno a ella hay muchas variantes, que hemos analizado en otra oportunidad ${ }^{45}$. Así, hay quienes, como Fix Zamudio, distinguen entre "Derecho Procesal Constitucional" y "Derecho Constitucional Procesal", y otros que simplemente se afilian al Derecho Procesal Constitucional a secas.

Por otro lado, sigue abierto el debate en torno a la naturaleza de este Derecho Procesal Constitucional. Algunos autores sostienen que es una disciplina constitucional (por ejemplo, Peter Häberle), otros afirman que es mixta (es el caso de Néstor P. Sagüés), y otros que la disciplina es netamente procesal. En lo personal, me inclino por esta postura, ya que existiendo un Derecho Procesal desarrollado científicamente desde fines del siglo pasado, es ése el lugar donde debe ir todo lo relacionado con los procesos que nacen de la Constitución, y que por eso son constitucionales ${ }^{46}$. Rubén Hernández Valle tiene razón cuando afirma que en el proceso constitucional se tutelan dos bienes jurídicos diferentes: los derechos fundamentales de los ciudadanos y el principio de la supremacía constitucional, y obviamente tales bienes jurídicos "condicionan" el Derecho Procesal Constitucional, pero no tiene razón el autor al pensar que estos dos elementos "constituyen el objeto y el contenido" del Derecho Procesal Constitucional ${ }^{47}$.

Más acertada es la opinión de Domingo García Belaunde quien enseña que el DPC es una rama del Derecho Procesal, que participa de su carácter como Derecho Público donde el proceso, como garantía es un solo y, por lo tanto, es como el tronco de un árbol del que salen varias ramas con singularidades propias ${ }^{48}$, en esta línea se define al proceso como género con procedimientos constitucionales que tienen configuraciones particulares. Comenta Gozainí que esta posición García "refleja, con algunos matices, la enseñanza editada en el año 1955 por Mauro Cappelletti,

45 Cfr. GARCÍA BELAUNDE, Domingo: "El Derecho Procesal Constitucional”, en Anuario de la Academia Peruana de Derecho, n 3. Lima, 1997.

46 Vid. GARCÍA BELAUNDE, Domingo: De la jurisdicción constitucional al Derecho Procesal Constitucional. FUNDAP. México, 2004, p. 18 y ss. Nos refiere el autor la existencia de una postura relativamente reciente, aun cuando minoritaria, sostenida por algunos juristas brasileños, como Marcus Orione Gonçalvez Correia, que considera que el Derecho Procesal Constitucional, siendo un tema netamente procesal, no es autónomo, sino que es parte del proceso civil, con lo cual el proceso civil tendría sus ramas, una de las cuales sería la constitucional, con carácter de subsidiaria y, en todo caso, ancilar. La tesis es sin lugar a dudas singular, porque pregona una minusvalía del proceso constitucional, haciéndolo depender del proceso civil, lo cual podría tener cierto valor a principios de siglo, pero no en la actualidad. Cfr. GONÇALVEZ CORREIA, Marcus Orione: Direito processual constitucional. Ed. Saraiva. São Paulo, 1988.

47 Vid. HERNÁNDEZ VALLE, Rubén: Derecho Procesal Constitucional. Ed. Juricentro. San José de Costa Rica, 1995, pp. 35-36.

48 Vid. GARCÍA BELAUNDE, Domingo: "El Derecho Procesal Constitucional y su configuración jurídica", en Revista Iberoamericana de Derecho Procesal Constitucional -Proces y Constitución- n 2, julio-diciembre, 2004. Ed. Porrúa. México, 2004, p. 48. 
que realizó una labor de Derecho comparado que publica con el título de Jurisdicción constitucional de la libertad" ${ }^{49}$.

Finalmente, la portentosa voz del maestro mexicano Fix Zamudio nos permite concluir que el Derecho Procesal Constitucional "tiene por objeto el análisis científico, desde la perspectiva de la teoría o doctrina general del proceso o del Derecho Procesal, de las garantías constitucionales establecidas por la Carta Federal de 1917, con sus numerosas reformas posteriores", advirtiendo no obstante que "debemos estar conscientes que hay una presencia de las diversas disciplinas procesales respecto del Derecho Sustantivo que es relativamente reciente y que ese desprendimiento ha sido paulatino, comenzando por el Derecho Procesal civil y penal, y sólo posteriormente los derechos procesales administrativos, de trabajo, agrario, etc. y una de las ramas más modernas, sino es que debe considerarse la mas actual, es precisamente el Derecho Procesal Constitucional" 50 .

Estas reflexiones no pueden soslayar las opiniones que afirman el carácter "constitucional" del DPC.

\subsubsection{El DPC como "Derecho Constitucional"}

El estudio que hace el maestro Nogueira Alcalá es sumamente ilustrativo para explicar algunas posiciones que estiman que el Derecho Procesal Constitucional forma parte del Derecho Constitucional ${ }^{51}$. Y en efecto, enseña que esta perspectiva es asumida en Alemania, por Peter Häberle, el cual considera al Derecho Procesal Constitucional como un derecho constitucional sustantivo y concretizado. Así lo explicita desde 1973 en Alemania, como él mismo lo señala, al sostener la peculiaridad del Derecho Procesal Constitucional, el cual considera emancipado del resto del Derecho Procesal, rechazando la doctrina de las lagunas según la cual debe aplicarse supletoriamente las normas procesales civiles ${ }^{52}$. El autor sostiene una

49 Cfr. GOZAINÍ, Osvaldo Alfredo: Introducción al Derecho Procesal Constitucional. Ed. Rubinzal-Culzoni. Santa Fe-Buenos Aires, 2006, p. 17.

50 FIX-ZAMUDIO, Héctor: Introducción al Derecho Procesal Constitucional. Ed. FUNDAP. Querétaro (México), 2002, p. 19 y ss.; del mismo autor es sumamente importante revisar "Breves reflexiones sobre el concepto y contenido del Derecho Procesal Constitucional," en Ferrer Mac-GREGOR, Eduardo: Derecho Procesal Constitucional. Ed. Porrúa, México, 2003, tomo I, p. 197; "La garantía jurisdiccional de la Constitución mexicana (Ensayo de una estructura procesal del Amparo)". UNAM, México, D.F., p. 57.

51 Véase NOGUEIRA ALCALÁ, Humberto: "Reflexiones sobre el Derecho Procesal Constitucional en América Latina", disponible en http://www.crdc.unige.it/docs/articles/ Procesal\%20constitucional.pdf [Consultado el 14 de julio de 2011]. Y también NOGUEIRA ALCALÁ, Humberto: "El Derecho Procesal Constitucional a inicios del Siglo XXI en América Latina", en Estudios constitucionales, vol. 7, Núm. 1, 2009, pp. 13-58. Centro de Estudios Constitucionales. Chile; disponible en http://redalyc.uaemex.mx/pdf/820/82011413003.pdf [Consultado el 14/07/2011].

52 Vid. HÄBERLE, Peter: El Tribunal Constitucional como Tribunal Ciudadano. El recurso constitucional de amparo. Ed. FUNDAP, México, 2005, pp. 78-79. 
interpretación que él denomina "específicamente jurídico-constitucional, donde hay que elaborar las normas de la Ley del Tribunal Constitucional Federal y los principios del Derecho Procesal Constitucional" 53 .

Häberle considera que "la Conexión funcional del Derecho Procesal Constitucional formal y el Derecho Constitucional Sustantivo es también consecuencia de la circunstancia de que el tribunal Constitucional Federal tiene el doble carácter de Tribunal y 'órgano constitucional'. La interpretación y concretización de la Constitución en los procesos especiales del Derecho Procesal Constitucional es parte de la Constitución como proceso público, lo que plantea exigencias específicas de racionalidad y aceptación. En los códigos procesales comunes, pueden descubrirse muchos conocimientos jurídicos y valores de experiencia, pero el tribunal Constitucional Federal puede modificarlos conforme a su estatus y una serie de resoluciones recientes muestran que el Tribunal lucha bastante por 'lo específico' del Derecho Procesal Constitucional. En otra publicación, el autor nos advierte:

El Derecho Procesal Constitucional, como Derecho Constitucional concretizado, significa necesariamente tomar un cierto distanciamiento de las demás normas procesales. No son una conversión de la Constitución al Derecho Procesal con la misma intensidad que lo son las leyes del TFCA, por más que ésta también está al servicio de la Constitución, de la misma manera que la legislación social está al servicio de los principios del Estado social. (...)

Sin embargo, esta autonomía tiene sus orígenes en una tradición mucho más antigua y variada, que se puede reconocer cuando el TFCA utiliza argumentativamente lo "auténtico" y lo "especial" del procedimiento constitucional, en tanto que establece un distanciamiento respecto de otras normas procesales.40 Sin embargo, esta independencia no es ni dogma, ni tiene fin absoluto. El TFCA procede con cautela, también utiliza principios del Derecho comparado dentro de los procesos alemanes, y se remite, además, a los principios generales del Derecho Procesal, etc. Ello, debido al carácter fragmentario de las normas procesales; y merece saludar este uso del Derecho comparado si ello aporta a las leyes del TFCA el bagaje de experiencia del llamado Derecho Procesal general, siempre y cuando, los fundamentos específicos de las leyes del TFCA no se vean afectados. El Derecho Procesal Constitucional "a la medida" de la Constitución y la teoría constitucional que se puede desprender a partir de ese Derecho, no excluye cautelosos "préstamos" del resto del Derecho Procesal ${ }^{54}$.

El autor no logró captar la absoluta independencia conceptual entre el Derecho Sustantivo (cualquiera que éste sea) con respecto de las instituciones procesales,

$53 \quad$ Ibídem, p. 79.

54 Vid. HÄBERLE, Peter: "El Derecho Procesal Constitucional como derecho constitucional concretizado frente a la judicatura del Tribunal Federal Constitucional alemán”, en Revista Iberoamericana de Derecho Procesal Constitucional, $\mathrm{n}^{\circ}$ 1, pp.15-44. Enero-junio. Editorial Porrúa. México, 2004, p. 24. 
pues la "especialidad" del Derecho Constitucional y sus rasgos esenciales, no desnaturalizan la función que realiza el juez constitucional quien, como cualquier otro juez, está en la obligación de otorgar efectiva tutela judicial en el marco de los procedimientos establecidos en la Ley. Hoy es insostenible pensar que el Derecho Procesal agrario sea "Derecho agrario", o que el Derecho Procesal del trabajo sea "Derecho del trabajo". De igual forma, que los procedimientos constitucionales tengan como "sustancia" el Derecho Constitucional, ello no le quita ni le agrega a su naturaleza procesal.

Por otro lado, Cesar Landa, magistrado del Tribunal Constitucional del Perú, se sitúa en la doctrina peruana en la tesis de Peter Häberle que considera al Derecho Procesal Constitucional como parte del Derecho Constitucional, como un "Derecho Constitucional concretizado". Así Landa sostendrá que "la judicatura constitucional debe contar no sólo con instancias y procedimientos propios, sino que requiere de principios y reglas autónomos que configuren un Derecho Procesal Constitucional, entendido como Derecho Constitucional concretizado lo que implica necesariamente tomar una cierta distancia con respecto a las demás normas procesales (P. Häberle). Pero, no se trata sólo de aplicar la Constitución en función de normas procedimentales, sino también de darles a dichas normas un contenido conforme a la Constitución, en el marco de una teoría constitucional que le otorgue sentido a la justicia constitucional" ${ }^{5}$. Cesar Landa precisará que "la autonomía procesal no es un dogma, sino un medio para la realización de la Constitución y para que el Tribunal Constitucional no acabe sumergido en la sobrecarga procesal, sino que se convierta en una magistratura garante de la libertad. Por ello, el Derecho Procesal Constitucional también requiere partir y remitirse a principios generales del Derecho Procesal, pero que no sean contradictorios con la justicia constitucional, sino que se desprendan de la Constitución" ${ }^{56}$. Por ello, el autor considerado precisará:

El Derecho Procesal Constitucional debe forjarse en concordancia con los aportes de la teoría constitucional, en materia de derechos fundamentales e interpretación constitucional; por cuanto sólo a partir de la praxis del estado constitucional y del desarrollo de dichos derechos y su interpretación, la teoría constitucional se convertirá en un factor principal de reflexión y de movilización del Derecho Procesal Constitucional ${ }^{57}$.

En esta perspectiva, se encuentra también en España, José Julio Fernández Rodríguez, para el cual el Derecho Procesal Constitucional se refiere al sector del ordenamiento jurídico que "regula los procesos constitucionales", tratándose de una disciplina preferentemente adjetiva, en las cuales no entran las cuestiones sustan-

\footnotetext{
55 Vid. LANDA, César: Teoría del Derecho Procesal Constitucional. Ed. Palestra). Lima, 2004, p. 13.

$56 \quad$ Ibídem, p. 13.

57 Locus cit.
} 
tivas y orgánicas. El Derecho Procesal Constitucional se integra en la "justicia o jurisdicción constitucional, materia que, a su vez, conforma un sector del Derecho Constitucional" 58 . "Las especificidades propias de la justicia constitucional son de tal importancia que le otorgan unos presupuestos metodológicos y epistemológicos propios al Derecho Procesal Constitucional. En todas estas cuestiones, señala el autor, hay que usar una óptica interpretativa específica del Derecho Constitucional al margen del Derecho Procesal General" ${ }^{59}$. Cierto que los principios, valores y hermenéutica propia del Derecho Sustantivo impactará el desarrollo del DPC, pero esto no es medular de esta ciencia. Por ello nos resultan totalmente acertadas las afirmaciones del ilustre jurista peruano Domingo García Belaunde:

Nuestra tesis es que el Derecho Procesal Constitucional es una rama del Derecho Procesal. (...)

Lo primero que debemos hacer es partir del hecho de que al ser parte del Derecho Procesal, el Derecho Procesal Constitucional arrastra una serie de conceptos del Derecho Procesal (o teoría del proceso, como también se estila) de los que es deudor y de los que se sirve. Pero a su vez, tiene otros que le son propios, y que le vienen de su peculiar naturaleza, que es servir de instrumento de realización del Derecho Constitucional ${ }^{60}$.

De allí que el autor precise tres rasgos característicos del naciente Derecho Procesal Constitucional: i) El Derecho Procesal Constitucional como queda dicho, es una rama o disciplina perteneciente al Derecho Procesal, de la que participa

58 Vid. FERNÁNDEZ RODRÍGUEZ, José Julio: "En respuesta a encuesta", en GARCÍA BELAÚNDE, Domingo y ESPINOSA-SALDAÑA BARRERA, Eloy (Coords.): Encuesta sobre Derecho Procesal Constitucional. Instituto Mexicano de Derecho Procesal Constitucional. Ed. Porrúa. México, 2006, p. 62.

59 Ibídem, in locus cit.

60 El autor afirma que "Históricamente, y si lo consideramos a partir de su configuración científica en el siglo XIX, vemos que el primero que fue objeto de un tratamiento adecuado fue el Derecho Procesal Civil, que es, por así decirlo, la madre de todos los procesos. Luego nació el Derecho Procesal Penal, y empezó la gran polémica en torno a la relación entre ellos, pues algunos aseguraban que se trataba de dos procesos distintos, y otros, que era el mismo proceso que se bifurcaba según sus necesidades. Y si bien la polémica no ha amainado, la tesis que hoy tiende a prevalecer, es que en el fondo el proceso es uno solo, y que por lo tanto, siguiendo la célebre metáfora de Carnelutti, el proceso sería al igual que el tronco de un árbol, del que saldrían varias ramas unidas al tronco común, pero con sus propias peculiaridades. Así considerados, los dos procesos por excelencia son el civil y el penal. Y el que ha avanzado mucho en los últimos tiempos, es el proceso administrativo, que todavía algunas legislaciones llaman o conocen como contencioso-administrativo, nombre impropio como en su día lo demostró ALCALÁ-ZAMORA. Y si admitimos la existencia de un proceso constitucional (que pueden, por cierto, ser varios), es inevitable que exista un Derecho Procesal Constitucional, como una de las ramas del Derecho Procesal general". Cfr. García Belaunde, Domingo: "El Derecho Procesal Constitucional y su configuración jurídica (aproximación al tema)", en Revista Iberoamericana de Derecho Procesal Constitucional, n² 2, pp.45-56. Julio-diciembre 2004. Editorial Porrúa. México, p. 47. 
en sus grandes lineamientos; ii) No obstante esto, y visto que el Derecho Procesal Constitucional instrumentaliza una problemática constitucional, tiene a su vez que desarrollar su propia parte general, fruto de su especial vinculación con el mundo constitucional, y acorde con la naturaleza peculiar de la norma constitucional; iii) Igualmente, tiene que tener presente los aspectos vinculados con la distribución territorial del poder en cada Estado en particular ${ }^{61}$.

\section{CONTENido ESENCIAL}

La conexión entre el Derecho Constitucional y el Derecho Procesal es absolutamente innegable, y en este sentido Zagrebelsky, apuntala que la jurisdicción constitucional y los procedimientos de aplicación de la Constitución para la resolución de casos controvertidos lleva aparejada una teoría de la Constitución como norma sustancial, cada concepción de la Constitución lleva aparejado una concretización del procedimiento, así como cada concepción del procedimiento lleva aparejada una concepción de la Constitución ${ }^{62}$. ¿Sobre qué debe ocuparse el Derecho Procesal Constitucional? Pablo Luis Manili ha sistematizado la problemática en las diversas posiciones que pueden identificarse:

i) Tesis restringida: La materia incluye el estudio de los procesos constitucionales (habeas corpus, amparo, acciones de inconstitucionalidad, etc.); en definitiva, lo que Mauro Cappelletti denomina “jurisdicción constitucional de libertad” y de la magistratura constitucional (es decir, el estudio de los órganos que la ejercen: tribunales constitucionales, cortes supremas, salas constitucionales, etcétera). La posición es asumida por Néstor Sagüés y el propio Manili ${ }^{63}$;

Como anunciamos, la posición es desarrollada por Néstor Sagüés, quién sostiene la existencia de una versión mínima del Derecho Procesal Constitucional, que lo entiende como una disciplina de carácter procesal y que tiene como temas centrales la magistratura constitucional y los procesos constitucionales, pudiendo sintetizarse en la jurisdicción constitucional. Así el Derecho Procesal o constitucional se ocuparía de los órganos y de los procesos que custodian la supremacía

${ }_{61} \quad$ Ibidem, pp. 475-56.

62 Vid. ZAGREBELSKY, Gustavo: ¿Derecho Procesal Constitucional? y otros ensayos de justicia constitucional. Ed. FUNDAP. México, 2004, pp. 17-18; véase también ANAYA, Salvador Enrique: "Aplicación de la Constitución y Derecho Procesal Constitucional”, en CASTAÑEDA OTSU, Susana Inés (Coord.): Derecho Procesal Constitucional. Jurista Editores. Lima, 2006, tomo I, p. 146 y ss.; también por RODRÍGUEZ DOMÍNGUEZ, Elvito: Manual de Derecho Procesal Constitucional. Ed. Grijley. Lima, 2006, p. 77.

63 Vid. SAGÜÉS, Néstor Pedro: Derecho Procesal Constitucional, 2002, p. 4; Cfr. MANILI, Juan Pablo: Introducción al Derecho Procesal Constitucional, 2005, pp. 31-32. 
de la Constitución ${ }^{64}$. Para Sagüés, el contenido básico del Derecho Procesal Constitucional sería la jurisdicción constitucional "comprensiva de la magistratura constitucional, u órgano de aquella, y los procesos constitucionales, que son los instrumentos destinados a asegurar la supremacía constitucional” ${ }^{65}$. Sagüés señala que ha adherido a la tesis restrictiva del Derecho Procesal Constitucional, aunque reconoce que numerosos programas de la asignatura se sitúan en una concepción amplia, y que el punto no está aún resuelto ${ }^{66}$.

ii) Tesis intermedia: Esta posición considera que el DPC incluye el estudio de los dos temas referidos (procesos constitucionales y magistratura constitucional), la llamada jurisdicción constitucional, esto es, el valor jurídico de la Constitución, el control constitucional, la interpretación constitucional, etc. La tesis es afirmada por el maestro Domingo García Belaúnde ${ }^{67}$;

En efecto, para García Belaúnde afirma que el contenido de la disciplina Derecho Procesal Constitucional está constituido básicamente por la jurisdicción constitucional, los procesos constitucionales y la magistratura constitucional ${ }^{68}$, sin perjuicio de distinguir entre un Derecho Procesal Constitucional general y un Derecho Procesal Constitucional particular, que es la disciplina desarrollada en torno a un país determinado. El autor analizado considera que el desarrollo del Derecho Procesal Constitucional se inicia con una parte general que considera la jurisdicción constitucional y los diversos modelos que se hayan desarrollado en la materia, la existencia de magistratura constitucional especializada y la existencia de diversos procesos constitucionales, además de tratar el Derecho Procesal Constitucional como disciplina relativamente autónoma ${ }^{69}$.

En una perspectiva similar se sitúa Juan Colombo Campbell en Chile, el cual señala que el DPC comprende el desarrollo de las siguientes áreas temáticas: i) El conflicto constitucional y sus formas de solución; ii) El Derecho Procesal

64 SAGÜÉS, Néstor Pedro: "Argentina”, en GARCÍA BELAÚNDE, Domingo y ESPINOSASALDAÑA BARRERA, Eloy (Coords.): Encuesta sobre Derecho Procesal Constitucional. Instituto Mexicano de Derecho Procesal Constitucional. Ed. Porrúa. México, 2006, pp. 21.

65 Vid. SAGÜÉS, Néstor Pedro: Derecho Procesal Constitucional, T.1, Recurso extraordinario, 1989 , p. 10 y ss.

66 SAGÜÉS, Néstor Pedro: Derecho Procesal Constitucional: logros y obstáculos. Ed. Ad-Hoc/ Konrad Adenauer Stifftung. Buenos Aires, 2006, p. 23; véase también SAGÜÉS, Néstor Pedro: Compendio de Derecho Procesal Constitucional. Editorial Astrea. Buenos Aires, 2009.

67 Cfr. GARCÍA BELAÚNDE, Domingo: De la jurisdicción constitucional al Derecho Procesal Constitucional. Ed. Grijley. Trujillo (Ecuador), 2003, p. 51.

68 Ídem, p. 60.

69 Cfr. GARCÍA BELAUNDE, Domingo: El Derecho Procesal Constitucional en perspectiva. Ed. Porrúa. México, 2008, p. 102. 
Constitucional orgánico, y iii) El Derecho Procesal Constitucional funcional” ${ }^{70}$; más adelante el autor determina como tareas del Derecho Procesal Constitucional: i) Velar por la aplicación del principio de la supremacía constitucional y de la eficacia de las garantías personales; ii) Solucionar los conflictos constitucionales; iii) Realizar la labor integradora de la justicia constitucional; iv) La defensa de la Constitución a través de su labor de intérprete de la Constitución, y, v) Colocar a disposición del Estado los elementos técnicos adecuados para que opere la Carta Fundamental ${ }^{71}$.

iii) Tesis amplia: Que a los temas anteriores agrega el estudio del debido proceso, sostenida por Osvaldo Alfredo Gozainí ${ }^{72}$, y Juan Carlos Hitters.

Para Juan Carlos Hitters, magistrado de la Corte Suprema de La Plata y procesalista argentino, el Derecho Procesal Constitucional regula el proceso constitucional y su objeto lo constituye la materia constitucional. Podemos decir que su contenido apunta a cuatro grandes vertientes: “(i) el debido proceso legal (ii) las garantías de las partes, (iii) las categorías de la jurisdicción, y (iv) las garantías judiciales" ${ }^{73}$. Asimismo, le reconoce al Derecho Procesal Constitucional "autonomía pedagógica y científica" ${ }^{74}$, estableciendo además que "[n] o obstante, hemos tratado de demostrar que pese a estar informada por los genes de aquellas dos grandes disciplinas, su esencia, es netamente procesal, pese a que también reconocimos lo difícil que resulta el encasillamiento, habida cuenta de lo ríspido que es la propia demarcación de los limbos del campo constitucional y los del procesal" 75 .

Una perspectiva similar asume Gozaíni, el que sostiene que el Derecho Procesal Constitucional se ocupa de la magistratura constitucional y del sistema procesal específico $^{76}$. En el ámbito de la magistratura constitucional, se pueden encontrar variantes de control constitucional difuso o concentrado, siendo los puntos de análisis: “(i) Los poderes del juez constitucional; (ii) la legitimación para actuar;

70 Vid. COLOMBO CAMPBELL, Juan: "Funciones del Derecho Procesal Constitucional”, en Revista Ius et Praxis, n 8. Chile, 2002, p. 13.

71 Ibídem, p. 30.

72 GOZAINÍ, Osvaldo Alfredo: El Derecho Procesal Constitucional y los Derechos humanos. Universidad Nacional Autónoma de México. Imprenta Universitaria. México, 1995, p. 77 y ss.

73 Vid. HITTERS, Juan Carlos: "El Derecho Procesal Constitucional", en FERRER MACGREGOR, E.: Derecho Procesal Constitucional. Ed. Porrúa. México, 1987, tomo I, p. 278.

74. Ibidem, p. 285.

75 Ibídem, locus cit.

76 GOZAINII, Osvaldo Alfredo: "Argentina", en GARCÍA BELAÚNDE, Domingo y ESPINOSASALDAÑA BARRERA, Eloy (Coords.): Encuesta sobre Derecho Procesal Constitucional. Instituto Mexicano de Derecho Procesal Constitucional. Ed. Porrúa. México, 2006, pp. 1112; del mismo autor puede verse El Derecho Procesal Constitucional y los derechos humanos (vínculos y autonomías). México. Ed. Universidad Nacional Autónoma de México. Imprenta Universitaria. México, 1995, p. 77 y ss. 
(iii) los contenidos de la sentencia judicial; (iv) los alcances y efectos de la cosa juzgada, entre otros" ${ }^{\prime 77}$. En el ámbito del debido proceso constitucional, deben ser considerados como puntos básicos: "(i) el acceso a la justicia; (ii) los principios de bilateralidad y de contradicción; (iii) la carga de la prueba; (iv) la fundamentación de las resoluciones judiciales; (v) la ejecución de la sentencia" ${ }^{78}$.

La primera posición nos resulta materialmente insuficiente pues al no incluir el tema de la "jurisdicción constitucional" (lo que denominamos anteriormente el "control anulatorio"), es dejar por fuera uno de los procedimientos más importantes, y si bien contiene un carga importante de "concepción constitucional" no puede olvidarse que, al fin y al cabo, constituye uno de los "procedimientos constitucionales" constitutivas del Derecho Procesal Constitucional. Por otro lado, la tesis amplia, nos resulta formalmente excesiva, pues las "garantías procesales" (efectiva tutela judicial, debido proceso, derecho de accionar, derecho a la defensa, etc.) constituye una "sustancia constitucional" aunque estén dirigidas a ser aplicadas en todos los procedimientos judiciales.

De allí que nos parezca absolutamente acertado la diferencia que hace el maestro Fix Zamudio entre el "Derecho Procesal Constitucional" y el "Derecho Constitucional del proceso" 79 . El primero de ellos responde a la categoría del "Derecho Procesal", mientras que el segundo es una manifestación específica del "Derecho Constitucional". Los instrumentos jurídicos del primero sólo tienen apli-

77 GOZAINÍ, Osvaldo Alfredo: “Argentina”, 2006, p. 12.

Ibídem, in locus cit.

79 Como afirma Mauro Cappelletti, la Jurisdicción Constitucional posee diversas formas de manifestación, tales como el control jurisdiccional de constitucionalidad de las leyes, el Mandato de Segurança, el Habeas Corpus, el Habeas Data, la Acción Popular, los institutos del Tribunal Constitucional Federal Alemán y las declaraciones de la Asamblea Popular de la ex-Unión Soviética, entre otras. El control jurisdiccional de constitucionalidad de las leyes es la vertiente más importante de la Jurisdicción Constitucional, pues, reproduciendo la teoría de Hans Kelsen, el control de la constitucionalidad de las normas -y la consecuente eliminación de las que sean inconstitucionales- "representa la garantía principal y más eficaz de la Constitución". Véase CAPPELLETTI, Mauro: O Controle Judicial de Constitucionalidade das Leis no Direito Comparado. Sergio Antonio Fabris Editor. Porto Alegre, 1999; J.J. Fernández Rodríguez, en relación a las competencias del Tribunal Constitucional, diferencia entre procesos constitucionales y procesos no constitucionales. A su vez, los procesos constitucionales pueden ser: I) Típicos: a) Control de constitucionalidad de las leyes -control abstracto y control concreto-; b) Defensa de los derechos fundamentales; c) Garantía de la distribución vertical y horizontal del poder; II) Atípicos: a) Control de las omisiones inconstitucionales. b) Control de constitucionalidad de tratados internacionales. c) Contencioso electoral. d) Control de partidos políticos; e) Interpretación obligatoria de la Constitución. f) Competencias con relación al jefe del Estado; g) Opinión sobre la reforma constitucional. Como procesos no constitucionales cita: 1) Control de constitucionalidad que no versa sobre normas legales. 2) Control con parámetro en los tratados internacionales; 3) Control de legalidad. 4) Control con parámetro infralegal. 5) Control no normativo. Vid. FERNÁNDEZ RODRÍGUEZ, José Julio: 2006. "En respuesta a encuesta". 
cación dentro de los procedimientos jurisdiccionales donde se debate una pretensión jurídico-constitucional, en cambio que las normas del Derecho Constitucional Procesal tienen virtualidad concreta de aplicación en todos los procedimientos judiciales dada la jerarquía de las normas constitucionales que postulan instituciones procesales.

\subsection{El interés constitucional}

Toda la actividad jurisdiccional tiene como núcleo esencial la existencia de un interés, esto es, aquella necesidad trascendente de un sujeto de carácter "objetivo" o "subjetivo" que tiene "cobertura jurídica" (posibilidad jurídica, en términos de Liebman), y que se procura ser satisfecha a través de un órgano jurisdiccional. El objeto de todo proceso judicial es la tutela de los intereses jurídicos, incluyo de aquél que pudiera ser, excepcionalmente, iniciado de oficio, pero mucho más en aquellos procedimientos iniciados por el requerimiento de las partes procesales. Hablar de "tutela" y "satisfacción de intereses" no supone otorgar lo que las partes solicitan, sino tan sólo conocer, tramitar, decidir y ejecutar - de ser el caso- las peticiones de las partes. Incluso en aquellas sentencias que ponen fin al procedimiento pero que no se pronuncian sobre la pretensión procesal (el caso típico son las decisiones que declaran la "perención de la instancia") se pronuncian sobre un "interés" que, en el caso de la figura señalada, se trata del "interés procesal".

Expliquemos esto un poco más: nadie acude a un juicio o un proceso judicial si carece absolutamente de "interés", pues como lo afirmara en su época el maestro colombiano, Hernando Devis Echandía, "nadie litiga por el mero gusto de litigar". Las personas acuden a los órganos judiciales por un "motivo" o una "causa" que consideran importante, y ese "motivo" es lo que constituye el "interés". Cuando ese interés está colocado como "supuesto de hecho" de una norma jurídica (Constitución, leyes, actos normativos sublegales, etc.), entonces estamos en presencia del "interés jurídico". Si el interés o la necesidad que se encuentra en su base, encuentra su satisfacción fuera del proceso, entonces ha funcionado el mecanismo de la "autocomposición"; pero, si el interés es resistido por quien tiene la obligación de satisfacerlo, entonces allí están abiertas las puertas de la jurisdicción para conocer, tramitar, decidir y ejecutar tales intereses. Este es el esquema básico del "conflicto", esto es, una "controversia trascendente de intereses" que el órgano jurisdiccional tiene la misión de "componer" a través del "proceso judicial", y ésta es también el esquema "tradicional" del proceso judicial: un mecanismo de solución o composición de conflictos y controversias.

Una nueva óptica se impone en la ciencia del proceso y que debe trascender al mito del "conflicto", pues a partir de la separación de la acción procesal con respecto del "derecho material" debatido, ya no es posible circunscribir el proceso judicial a la mera composición de los conflictos. La nueva dimensión ontológica del objeto del proceso hay que buscarlo en los "intereses jurídicos", pues no son pocos los 
ejemplos en los cuales el proceso judicial no se dirige al conflicto, de hecho, puede no existir el conflicto, sin embargo siempre se procurará la tutela de un interés. Esta observación es tan importante, a los efectos del Derecho Procesal Constitucional, que el objeto de los diferentes procedimientos no necesariamente versan sobre "conflictos" sino sobre "intereses", tampoco el conflicto es ajeno pues, al contrario, es el primer dato para hurgar sobre el objeto del proceso, pero no es ni el más importante ni mucho menos exclusivo. En este punto resulta indispensable para colaborar con aquellos lectores que no están familiarizados con las instituciones procesales, que hagamos una importante diferencia:

i) El "interés material": Las reflexiones anteriores versan sobre el interés material de carácter sustantivo que, en nuestro caso, está regido por el Derecho Constitucional, y forma parte del Derecho Sustantivo constitucional;

ii) El "interés procesal": Que tiene que ver con el "impulso procesal", esto es, el conjunto de diligencias y actuaciones que las partes deben realizar durante todo el procedimiento para llevar el juicio hasta su destino normal que es la sentencia; se trata de un interés procesal de carácter formal que es absolutamente independiente del interés material aunque exista una relación de subordinación y de instrumentalidad. El interés procesal es, sin duda, secundario al servicio de los derechos e intereses de fondo que se debaten en cualquier procedimiento judicial $^{80}$.

Esta diferencia no es caprichosa sino que ha sido el resultado de una lenta evolución del Derecho Procesal bajo el liderazgo de la escuela científica alemana y la escuela sistemática italiana. Si tuviéramos mayor espacio en esta obra profundizaríamos sobre la tesis de que el "interés procesal es a la acción, lo que el interés material es a la pretensión". El tema del "interés constitucional" que anima el alma del Derecho Procesal Constitucional puede ser analizado desde dos perspectivas: i) La tutela objetiva de un interés constitucional en la supremacía de la Constitución y el orden público constitucional; y, ii) La invocación de tutela a un "interés constitucional" subjetivo que se manifiesta frente a la amenaza o la lesión a derechos y garantías constitucionales, previamente poseídas por el querellante.

Así, por ejemplo, el llamado "control concentrado o abstracto" de la constitucionalidad que ejerce, en exclusiva, la Sala Constitucional de nuestro Tribunal Supremo de Justicia, es una manifestación de la "tutela objetiva y abstracta" como "cometido

80 Para los procesalistas esta temática es absolutamente importante pues permite ubicar "sistemáticamente" las diversas instituciones procesales en sus diferentes "categorías jurídicas" que no otro propósito tiene la ciencia procesal; pues bien, para el análisis de las relaciones entre el "interés" y la "acción procesal", así como la importancia del interés material para fijar la “pretensión procesal", la competencia del órgano jurisdiccional, y el procedimiento legalmente aplicable debemos recomendar nuestra obra La teoría general de la acción en la tutela de los intereses jurídicos. Ed. Frónesis. Caracas, segunda edición, 2011. 
primario" de la jurisdicción constitucional; mientras que, el llamado "control difuso o concreto" se produce el marco de una relación jurídico-procesal específica, y sólo supone la "inaplicación preventiva" de una norma legal que, supuestamente debe reputarse inconstitucional. En este caso, es una manifestación de la "justicia constitucional", y que además puede ser ejercido por todos los tribunales de la República.

Otra manifestación del "interés subjetivo constitucional" se manifiesta en aquellos procedimientos constitucionales cuyo fin primario es la garantía y tutela de los ciudadanos frente al actuar de los órganos del Poder Público en sus diferentes manifestaciones, y para ello se dispone el procedimiento de amparo constitucional, procedimiento de habeas data, procedimiento de habeas corpus, etc. En estos casos la tutela "primaria" es sobre un evidente interés particular sin desconocer que "mediatamente" se logra garantizar la "integridad" y "supremacía constitucional" pero sólo como "consecuencia". Este aspecto es llamado por Cappelletti ${ }^{81}$ como "jurisdicción constitucional de libertad" para referirse a los instrumentos establecidos en las cartas constitucionales -agregaríamos también en la legislación ordinaria- para la protección de los derechos y garantías fundamentales. El interés constitucional también podrá estar referido, como aprecia Gozainí, a un segundo sector radicado en la "defensa constitucional", esto es, la fiscalización de la supremacía y la resolución de los conflictos internos de poder; y en tercer lugar, un sector de carácter "transnacional o internacional" "por el cual se pueden colegir o interpretar las normas de dicho carácter que se incorporan en los Estados como una forma de garantizar la difusión, promoción y protección de los derechos humanos" ${ }^{82}$.

\subsubsection{El interés constitucional objetivo}

En este supuesto la "necesidad" del justiciable no viene dado por una afección en sus derechos o garantías, o a su esfera individual y concreta, sino que precisa la intervención del órgano jurisdiccional constitucional con el mero propósito o motivo de encontrar una "juicio" abstracto y objetivo sobre una pretensión específica, por ejemplo, la pretensión de nulidad de una norma legal por motivos de inconstitucionalidad; también puede entrar dentro de estas categorías la "pretensión de interpretación” de normas constitucionales, e incluso la pretensión por controversia constitucional que, en muchas ocasiones, no supone efectivamente un "conflicto" sino la necesidad de "aclarar" el ámbito de competencia constitucional de diversos órganos del Poder Público. Tanto en la pretensión de nulidad como en la interpretación constitucional no existe un "conflicto intersubjetivo" de intereses donde un sujeto persigue la "subordinación de la voluntad ajena" que es la visión

81 Cfr. CAPPELLETTI, Mauro: La justicia constitucional (Estudios de Derecho Comparado). Universidad Nacional Autónoma de México. Instituto de Estudios Jurídicos. México, 1987.

82 Vid. GOZAINÍ, Osvaldo Alfredo: Introducción al Derecho Procesal Constitucional. Ed. Rubinzal-Culzoni. Buenos Aires-Santa Fe, 2006, p. 15. 
clásica de la litis en Francesco Carnelutti; quien pretende "extender" el concepto al punto de plantear que en el recurso de nulidad existe un "conflicto" entre la Ley y la Constitución, deben consentir que no es ese el sentido en que la expresión se usa en el Derecho Procesal.

Con razón se ha planteado que, en este tipo de procedimientos, se plantea un "juicio objetivo", de carácter "abstracto" donde lo que se "enjuicia objetivamente" es la contradicción o contrariedad de la Ley con respecto de la supremacía constitucional. En este sentido la Sala Constitucional ha deslindado el "interés subjetivo" del especial interés jurídico que se tutela en este procedimiento:

Sala Constitucional: Sentencia $n^{\circ} 1.185$ de 17 de junio de 2004 (Petróleos de Venezuela en exp. 03-0775) [José Delgado Ocando]: "Los procesos seguidos ante la jurisdicción constitucional, a diferencia de los lleva-dos en el contencioso administrativo o, inclusive, ante la denominada jurisdicción ordinaria, se caracterizan por-que el interés que asiste a un individuo en particular para recurrir no se encuentra comprendido de manera exclusiva y excluyente en un interés procesal que le es propio, por no haber una contención propiamente dicha que lo antagonice contra derechos y obligaciones pertenecientes o recaídas en una contraparte. Tal afirmación se sustenta en razón de que el proceso relacionado con el control concentrado de la constitucionalidad devenga de la necesidad de que se revise el acto cuya inconstitucionalidad se denuncia, siendo un juicio que obra más por caracteres objetivos -estudio del acto respecto a la Constitución- que en defensa de la esfera de derechos subjetivos de los particulares, a diferencia del caso del amparo constitucional, donde este elemento tiene una importancia fundamental.

Denotados los procedimientos de con-trol concentrado de la constitucionalidad bajo un carácter objetivo -sin que ello implique desmedro alguno del interés que puede tener la parte en recurrir- es que en reiteradas ocasiones se ha señalado que los casos en que se analice la constitucionalidad de un determinado acto no puedan catalogarse dentro de la figura de los procedimientos contenciosos. A diferencia de lo que ocurre en el contencioso administrativo, donde se exige que la parte tenga un interés personal, legítimo y directo -con ciertas relajaciones en razón de las últimas posturas de la jurisprudencia en esta materia- y que permite la participación de otras partes además de la Administración, como ocurre, entre otros muchos, con los denominados actos cuasi jurisdiccionales; y en los juicios entre particulares donde se discuten la titularidad de un derecho o el cumplimiento de una obligación, la jurisdicción constitucional permite de manera amplia que cualquier persona que determine la posibilidad de existencia de una vulneración constitucional recurra de ese acto".

Veamos las afirmaciones de la Sala que nos interesan resaltar: a) En los procesos constitucionales se caracterizan porque "el interés que asiste a un individuo en particular para recurrir no se encuentra comprendido de manera exclusiva y excluyente en un interés procesal [Rectius: interés material] que le es propio", y b) "la necesidad 
de que se revise el acto cuya inconstitucionalidad se denuncia, siendo un juicio que obra más por caracteres objetivos". El carácter objetivo del juicio de nulidad ha servido para analizar la legitimación o cualidad para acudir a juicio, y en esta misma decisión la Sala Constitucional concluyó: "al mantenerse la amplitud para recurrir en inconstitucionalidad de cualquier acto, y delimitado que ello comporta un juicio objetivo del mismo, es que debe referirse que toda persona convocada al proceso posee la misma cualidad para recurrir, sin que exista un interés o derecho que lo haga preferente de otras personas que acudan a ejercer su pretensión”. El carácter "objetivo" de la pretensión de nulidad por inconstitucionalidad viene dado porque el "interés" postulado se contrae, primariamente, al mantenimiento del orden constitucional, aun cuando ello no significa que no pueda favorecer la posición subjetiva de un sujeto o un grupo de individuos. La posición había sido asumida desde hace mucho tiempo por la Corte Federal y de Casación cuando afirmaba que "en el recurso de inconstitucionalidad, no hay partes, porque no hay un procedimiento contencioso" (vid. s. 30/7/57), reiterada en decisión de la SPA de la Corte Suprema de Justicia, en su sentencia de 19 de febrero de 1981:

\begin{abstract}
"es de doctrina, y así lo tiene establecido la Corte en reiterada jurisprudencia, que este recurso (de inconstitucionalidad) es el que corresponde a cualquier ciudadano, que en tal situación actúa como parte legítima 'para impugnar la validez de un acto del Poder Público, que por tener un carácter normativo y general, obra erga onmes $y$, por tanto, su vigencia afecta e interesa a todos por igual", es que se fundamentó en el artículo 112 de la Ley Orgánica de la Corte Suprema de Justicia la amplitud de la legitimación para recurrir en inconstitucionalidad, tal como lo señalase la Exposición de Motivos cuando esta Ley estaba en anteproyecto: "En efecto, el recurso contencioso administrativo, por versar sobre un acto de efectos particulares, es decir, un acto que se concreta a una de-terminada persona o a una categoría de personas perfectamente individualizadas, es un recurso subjetivo y, en consecuencia, exige un interés calificado en el recurrente, un lapso para impugnar el acto y ciertos requisitos en cuanto a la documentación de la demanda. El acto general, en cambio, por ser un acto que afecta en igual medida a toda la colectividad o a un sector de la misma, cuyos componentes no se pueden identificar, como re-curso objetivo, requiere de un tratamiento especial para impugnarlo, en cuyo caso se justifica la acción popular, que hemos descrito". Con base en lo expuesto, se dictó el lineamiento relacionado con la legitimación para interponer el recurso nulidad por inconstitucionalidad que, si bien en un principio, se creyó que su titularidad de ejercicio había quedado reducida, ésta más bien se conservó, según lo decidió la Corte Suprema de Justicia”.
\end{abstract}

La afirmación según la cual en este tipo de juicios "no hay partes" sólo es explicable porque, para ese momento, la ciencia procesal se encontraba en franco proceso de transformación, conforme a lo cual identificar la noción de "partes procesales" con la idea del "conflicto" o con lo "contencioso", resulta superado. El concepto de parte procesal se identifica con los titulares de los intereses jurídicos, 
aunque sea bajo la figura de la "autoatribución" y que se postulan en cualquier tipo de procedimiento, pues la noción de parte se refiere a un status o una "posición" que se concreta en el procedimiento. Esto nos permite afirmar que, a pesar del carácter "objetivo" del "interés constitucional", existen verdaderas "partes procesales", carácter que asumen quienes acuden al procedimiento. Sin embargo, a los efectos de este epígrafe, lo cierto es que el "interés jurídico" evidenciado en la pretensión de nulidad, tanto de actos normativos de rango legal como aquellos actos administrativos de efectos generales normativos, es de carácter "objetivo" sin que se pretenda, como dato primario, la modificación del status jurídico de quien postula en el proceso. En otra sentencia, la antigua Corte Suprema de Justicia en sentencia de 6 de octubre de 1998, explicó:

“1) El carácter objetivo del recurso de nulidad por inconstitucionalidad, permite advertir que el mismo se encuentra depurado de las pretensiones formuladas por la recurrente en cuanto a: la existencia de la Comunidad Indígena de la etnia Kari'ña que habita las tierras de "El Guamo"; la existencia del título de propiedad de las referidas tierras, a favor de la Comunidad Indígena Jesús, María y José de Aguasay; la nulidad de los actos mediante los cuales, con base en los artículos impugnados, se concedieron arrendamientos a terceros; y el restablecimiento de las situaciones subjetivas lesionadas, poniendo en posesión de las tierras a la recurrente; en el contexto del recurso de nulidad, mediante decisiones mero declarativas, reivindicatorias o interdictos restitutorios de posesión.

La solución debe limitarse a dirimir la petición de la declaratoria de nulidad en sí, habida cuenta de que la acción de inconstitucionalidad es de naturaleza eminentemente objetiva, porque está dirimida a la preservación del orden constitucional, y no al control de conflictos intersubjetivos de derechos. $\mathrm{La}$ finalidad del recurso de inconstitucionalidad -se reitera- no es precisamente la defensa, protección o tuición de los derechos subjetivos, o de los intereses legítimos de los ciudadanos en particular, sino la defensa objetiva de la majestad de la Constitución y su supremacía"s3.

Este carácter "objetivo" de la pretensión nulificatoria de leyes es un rasgo presente también en el llamado "recurso de interpretación" e incluso en el recurso de revisión extraordinaria de sentencias, y sin que esta perspectiva se constituya en un mito, no debe dejarse de lado que, en el marco del Derecho Procesal Constitucional también pueden tutelarse intereses de carácter "individual" o "subjetivo"; el elemento central para identificar el carácter "objetivo/subjetivo" del interés es precisar ¿Cuál es el interés preponderante, primario o causal?, y como sabemos, determinando el interés puede identificarse de manera más sencilla, lo relacionado con la "cualidad" o "legitimación".

83 Véase la referencia en Venezuela. Sala Político-Administrativa: Sentencia n ${ }^{\circ} 1.035$ de 27 de abril de 2006 (Municipio Aguasay del Estado Monagas vs Comunidad Indígena Jesús María y José de Aguasay, exp. 1999-16135). 


\subsubsection{La tutela primaria de intereses subjetivos}

La existencia de un juicio de carácter "objetivo" en los procedimientos constitucionales, no desdice la posible tutela de intereses de carácter personal derivados de un conflicto trascendente, lo cual puede ocurrir entre particulares, entre particulares y los entes públicos, o entre entes públicos. De manera que el "interés constitucional", en estos casos, pueden ser de carácter individual, colectivo, difuso, general, etc., pero lo importante es que de tales varios intereses pueden encontrarse en estado de "contención" o de posiciones encontradas. Es el caso típico de la pretensión de amparo constitucional que interpone un ciudadano contra otro particular o contra un órgano o ente de carácter público, cuando sus derechos o garantías se vean conculcados o simplemente amenazados. Otro ejemplo que permite evidenciar la posible existencia de "conflictos trascendentes" de carácter constitucional, es la pretensión por controversia constitucional de competencia, denominado "conflicto de poderes", pues efectivamente dos o más órganos o entes del Poder Público se disputan determinado ejercicio de alguna competencia. Antes habíamos señalado que este tipo de "controversia" no necesariamente supone un "conflicto", pues es bien posible que los entes públicos involucrados sólo tengan como propósito la claridad o interpretación auténtica sobre la "titularidad" de determinada atribución pública.

Al lado de las pretensiones constitucionales reseñadas, encontramos la "pretensión por habeas data" que constituye un mecanismo especial para la tutela directa del derecho a la autodeterminación informativa, o como medio instrumental de defensa de otros derechos constitucionales como la vida privada, intimidad, honor, reputación, etc. En ambos casos, tanto la pretensión como el procedimiento tienen como finalidad la tutela inmediata de un "interés" de carácter constitucional implícito en el derecho fundamental de control de la información personal o patrimonial, en los términos establecidos en el artículo 28 constitucional. Por esta característica tendemos a estar de acuerdo con Luigi Ferrajoli cuando califica el establecimiento del Derecho Procesal Constitucional como "la conquista más importante del Derecho contemporáneo para el logro de la protección jurisdiccional de la dignidad de las personas y de los derechos fundamentales frente a la ley, los que no podrían sobrevivir si carecen de una tutela eficaz a través del proceso", pero que extenderíamos no sólo "frente a la Ley" sino frente a cualquier situación que pueda comprometer el "interés constitucional"; de allí que Colombo Campbell acertadamente aprecie que "es correcta la denominación de Derecho Procesal Constitucional, puesto que su contenido se refiere a la competencia jurisdiccional constitucional y al proceso que debe seguirse para decidir sobre las garantías y no a preceptos constitucionales que se encuadran en el marco de la Constitución en forma estática" ${ }^{84}$.

84 Véase COLOMBO CAMPBELL, Juan: "Funciones del Derecho Procesal Constitucional", en Revista Ius et Praxis. 2002, vol. 8, n. 2, pp. 11-69. Disponible en: http://www.scielo.cl/scielo.php?script=sci_arttext\&pid $=$ S0718-00122002000200002\&lng=es\&nrm=iso $>$. ISSN 0718- 


\subsubsection{La pretensión jurídico-constitucional}

Si el tema del "interés constitucional" resulta apasionante, cuando nos detenemos a analizar la configuración de la "pretensión procesal" en los procedimientos constitucionales, el panorama se nos presenta subyugante y con mayor claridad. En efecto, el interés jurídico se postula en los procesos judiciales en este instituto de primera importancia: la pretensión jurídico-constitucional, es decir, aquello que el sujeto requiere y que pide ante los órganos jurisdiccionales competentes. La expresión formal del interés es la pretensión, pues detrás de cualquier pretensión que se postule en un proceso judicial siempre estará presente la invocación de tutela de un interés, sea objetivo o subjetivo.

La pretensión jurídica se configura o se plasma formalmente en el libelo de la demanda, querella, solicitud, etc., y conjuntamente con la pretensión del demandado, querellado o la persona que se presente a juicio con interés, configuran una segunda noción diferente aunque vinculada: la pretensión procesal. Desde este punto de vista, la "pretensión procesal" se configura con la presentación del libelo de la demanda donde el actor o solicitante define su pretensión jurídica, y la contestación de la demanda donde el demandado o los demás interesados, postulan sus propios intereses. ¿Cuál es la importancia de determinar la pretensión jurídicoconstitucional? Tanta importancia merece que, a través de ella a) se determina la "competencia" constitucional; b) se establece el procedimiento aplicable; y c) se prepara el thema decidendum, es decir, el ámbito material sobre el cual, el órgano jurisdiccional deberá pronunciarse. La preeminencia del "interés constitucional" (la específica tutela requerida al órgano jurisdiccional) postulada en la pretensión, es tan importante en los procedimientos constitucionales que la Sala Constitucional se ha permitido establecer el criterio según el cual la Sala puede "cambiar" el cauce procesal requerido por el justiciable para, en su lugar, tramitarlo por el procedimiento correcto, cosa que en el procedimiento civil es impensable:

Venezuela. Sala Constitucional: Sentencia n 1.005 de 29 de mayo de 2002 (Asociación Civil Consorcio Justicia y otro en recurso de interpretación, exp. 01-2484) [Pedro Rondón Haaz]: "Reconducir demandas que cursen por ante esta Sala Constitucional es una facultad de la que se ha dispuesto en varias oportunidades con el fin de adecuar su trámite a la naturaleza de la pretensión que en las mismas se deduce. Ello encuentra justificación en el ejercicio de la función de garantía constitucional, más atenta a los hechos o situaciones que constituyen la denuncia, que a las categorías o

0012. doi: 10.4067/S0718-00122002000200002 [Consultado el 17/07/2011], véase también, del mismo autor, "Enfoques conceptuales y caracterización del Derecho Procesal Constitucional a principios del siglo XXI", en FERRER MAC-GREGOR, Eduardo y ZALDÍVAR LELO, Arturo (Coord): La ciencia del Derecho Procesal Constitucional. Estudios en homenaje a Héctor Fix Zamudio en sus cincuenta años como investigador del Derecho. Instituto de Investigaciones Jurídicas. Universidad Nacional Autónoma de México. Ed. Marcial Pons. México, p. 317 y ss. 
conceptos que utilizan los demandantes. Así, y tal como lo expresó la Sala en sentencia $n^{\circ} 8 / 2000$ y lo ratificó en sentencia $n^{\circ} 1225 / 2000$, “...como protector de la Constitución y de su aplicación en todos los ámbitos de la vida del país (...) existe el interés constitucional de que quienes pidan la intervención del poder judicial en el orden constitucional reciban efectivamente los beneficios constitucionales, sin desviaciones o minimizaciones causadas por carencias o errores en el objeto de las peticiones (...)".

Provista de esta facultad, y luego de una atenta lectura de los escritos presentados por los demandantes, considera esta Sala que la pretensión propuesta, más que la interpretación de normas constitucionales, persigue la nulidad por razones de inconstitucionalidad de los artículos 10, 11, 26 y 52 de la Ley Orgánica de Justicia de Paz. Por lo tanto, estima esta Sala que la misma debe tramitarse conforme al procedimiento que corresponde a las demandas de nulidad por inconstitucionalidad, dispuesto en la Sección Segunda, Capítulo II, Título V de la Ley Orgánica de la Corte Suprema de Justicia. Así se establece. Ello no obsta para que, en la sentencia definitiva, esta Sala interprete, en el ejercicio de sus potestades, las normas constitucionales aludidas por la parte actora. Siendo entonces que en el caso sub examine se propuso la declaratoria de nulidad por razones de inconstitucionalidad de los artículos 10, 11, 26 y 52 de la Ley Orgánica de Justicia de Paz, esta Sala se declara competente para conocer del presente asunto conforme con lo dispuesto en el cardinal 1 del artículo 336 de la Constitución".

El criterio es que, en los procedimientos constitucionales, el órgano jurisdiccional está habilitado para "cambiar" el procedimiento requerido por el justiciables y tramitarlo de conformidad con lo que corresponda. La tesis es peligrosa pues, en el afán de "cambiar" el procedimiento puede cambiarse también la "pretensión" y ello sí no es posible en el marco de una teoría general del proceso. La Sala puede, de oficio, entrar a decidir una inconstitucionalidad no invocada o no pedida, pero lo que no puede la Sala es transmutar la pretensión jurídica invocada por lo que, la Sala eventualmente, pudiera creer subjetivamente. En la sentencia citada, por ejemplo, los justiciables pedían una "interpretación” pero la Sala, sobre la idea de "cambiar el procedimiento" en realidad cambió la pretensión a una pretensión de nulidad. Ello no es posible, ni siquiera en el marco de los procedimientos constitucionales.

Sin embargo, la sentencia tiene pertinencia porque lo que sí es indispensable para el órgano jurisdiccional, es "identificar" el "interés constitucional", y ciertamente como afirma la Sala ese interés abraza la idea de que "quienes pidan la intervención del poder judicial en el orden constitucional reciban efectivamente los beneficios constitucionales, sin desviaciones o minimizaciones causadas por carencias o errores en el objeto de las peticiones". Unos años antes, la Sala había afirmado: "Cabe acotar, que la reconducción de la acción aclaratoria pedida por el accionante a un recurso por inconstitucionalidad, se efectúa atendiendo a la entidad de la función de protección constitucional, más atenta a los hechos o situaciones que constituyan la denuncia, que a las categorías o conceptos utilizados por los denun- 
ciantes, ya que, "como protector de la Constitución y de su aplicación en todos los ámbitos de la vida del país (...) existe el interés constitucional de que quienes pidan la intervención del poder judicial en el orden constitucional reciban efectivamente los beneficios constitucionales, sin desviaciones o minimizaciones causadas por carencias o errores en el objeto de las peticiones..." (Sentencia de la Sala no 8/2000, p. 8$)^{\prime \prime}$.

Ahora bien ¿Cuáles son las pretensiones jurídico-constitucionales? La respuesta determina el "objeto" y "contenido" del Derecho Procesal Constitucional, en nuestro país. No es éste el espacio para discurrir sobre las diferentes posiciones doctrinarias en torno a este contenido sobre lo cual hemos destinado un estudio especial ${ }^{86}$, pero resulta importante conocer que al hablar de "procedimientos constitucionales" nos centramos en ese "contenido" u "objeto" en nuestro país:

i) La pretensión de amparo constitucional, cuya competencia se distribuye hacia todos los órganos jurisdiccionales con base en su competencia material, de modo que conocen de este tipo de pretensiones aquellos tribunales cuya competencia sea afín con la naturaleza del derecho o garantía constitucional lesionadas o amenazadas de violación, salvo la competencia expresa de la Sala para conocer de las pretensiones dirigidas contra entes o altos funcionarios del Poder Público (art. $8^{\circ}$ LOASDGC).

ii) La pretensión de nulidad de actos normativos dictados por los órganos del Poder Público (República, Estados y Municipios), en ejecución directa e inmediata de la Constitución. Esta pretensión es del conocimiento exclusivo de la Sala Constitucional del Tribunal Supremo de Justicia.

iii) La pretensión de revisión extraordinaria de sentencias definitivamente firmes que contraríen normas constitucionales, o se aparten de alguna interpretación vinculante que hubiera realizado la Sala Constitucional con anterioridad; este tipo de pretensiones también le corresponde a la Sala Constitucional bajo la consideración de "competencia exclusiva".

iv) La pretensión por omisión legislativa que supone que un determinado parlamento no cumpla con alguna obligación específica impuesta por la Constitución, en cuyo caso, en exclusiva, la Sala Constitucional entra a analizar el mérito de la obligación, el tiempo en que debió cumplirla el ente público de que se trate, y aunque se discuta, la Sala puede fijar algunos "lineamientos generales" de comportamiento con carácter provisional, mientras el Parlamento respectivo cumple con su obligación.

85 Véase sentencia de la Sala Constitucional n 1.225 de 19 de octubre de 2000 (Ascander Contreras Uzcátegui en nulidad de la Ley de Universidades y Reglamentación Electoral Universitaria), exp. 00-1141.

86 Vid. ORTIZ-ORTIZ, Rafael: Constitución y proceso. Una introducción al Derecho Procesal Constitucional. Ed. Frónesis. Caracas, 2011. 
v) La pretensión por conflicto de poderes que supone la necesidad o el interés de dos o más entes públicos en determinar el ámbito específico de sus propias competencias constitucionales.

vi) La pretensión por colisión normativa, que es un modo de conflicto de poder, en tanto que supone dos normas igualmente vigentes, de igual jerarquía y grado de especialidad, lo cual supone que la Sala ejerza su potestad de interpretación para fijar cuál debe ser la norma jurídica prevalente.

vii) La pretensión de "control" de la constitucionalidad de algunas competencias de algunos órganos o entes públicos, por ejemplo, el control previo de la constitucionalidad de aquellas leyes que, el Parlamento Nacional, haya atribuido el carácter "orgánico"; también ejercer este tipo de control, en los supuestos en que los demás tribunales hubieren ejercido el "control difuso de constitucionalidad" de alguna norma jurídica vigente, pues en tales casos la "desaplicación de la norma" estará sujeta a la confirmación posterior de la Sala Constitucional.

viii)La pretensión por habeas data, la cual supone el "interés constitucional" de obtener una tutela sobre el Derecho fundamental de autodeterminación informativa, o la tutela instrumental de derechos y garantías constitucionales mediante el acceso, actualización, supresión, inclusión, corrección, de aquellas informaciones que se encuentren en bases de datos públicos o privados. En este caso la competencia procesal se le ha atribuido a los Juzgados Contencioso-Administrativos de Municipio.

ix) La pretensión de interpretación constitucional que es un mecanismo por el cual la Sala, previa solicitud de parte, determina el sentido y alcance de normas constitucionales sobre las cuales exista alguna duda "razonable" y "objetiva", es decir con independencia de algún interés particular que se debata en algún procedimiento judicial.

Algunos autores consideran que aquellas pretensiones que tienen como propósito la tutela de intereses colectivos o difusos, constituye otro tipo de "pretensiones constitucionales" o de "procedimientos constitucionales". A nuestro modo de ver, si bien este tipo de pretensiones pudieran tener un "interés constitucional" sin embargo éste no es prevalente, y tampoco constituye el núcleo de la pretensión jurídica del solicitante. La diferencia entre estos intereses suprapersonales con respecto de las pretensiones ordinarias no es su carácter o rango constitucional que bien pudiera no existir, sino específicamente en la "legitimidad" para acudir a un juicio, los "efectos de la sentencia", y sobre todo en la manera de satisfacer el interés que resulta inescindible en relación con las varias personas titulares de tal interés suprapersonal.

Aunque, la pretensión por intereses colectivos y difusos haya sido regulada por la Ley Orgánica del Tribunal Supremo de Justicia, en el mismo Título que los 
procedimientos constitucionales, es sólo un aspecto formal que, para nada, determina la naturaleza constitucional de la pretensión o del procedimiento. De hecho, la competencia corresponde, primariamente, a los Juzgados con competencia civil $\mathrm{y}$, excepcionalmente, esto es, cuando tales intereses puedan afectar severamente al interés general, entonces la Sala Constitucional pudiera conocer. La Ley Orgánica del TSJ establece: "Artículo 146. Toda persona podrá demandar la protección de sus derechos e intereses colectivos o difusos. Salvo lo dispuesto en leyes especiales, cuando los hechos que se describan posean trascendencia nacional su conocimiento corresponderá a la Sala Constitucional; en caso contrario, corresponderá a los tribunales de primera instancia civil de la localidad donde aquellos se hayan generado. (...)"

Una cosa es que la Sala Constitucional tenga competencia para conocer determinada pretensión, y otra muy distinta es que ese sea el elemento que cualifica una pretensión jurídico-constitucional, pues como lo hemos evidenciado en las reflexiones anteriores, el elemento central o nuclear de este tipo de pretensiones es la existencia de un "interés jurídico-constitucional", y resulta claro que los intereses colectivos o difusos no necesariamente pudieran comportar la aplicación del Derecho Sustantivo constitucional. Por otro lado, hay que distinguir la "competencia procesal" que puede ejercer la Sala Constitucional y la "pretensión jurídica" que determina la existencia de un "procedimiento constitucional", pues no siempre coinciden, de manera que la Sala puede conocer de determinada pretensión y ello no necesariamente genera un procedimiento constitucional, dado que estos procedimientos son mecanismos de tutela judicial fundada directamente en derechos y garantías constitucionales, o la salvaguarda del orden constitucional.

\subsection{Interés, pretensión y orden público constitucional}

A raíz de la identificación del "interés constitucional" la Sala no sólo ha "reconducido" la pretensión del justiciable, sino que, a pesar de estimar inadmisible la pretensión ha justificado el actuar de oficio en aras del "orden público constitucional", ello implica que el "interés subjetivo" puede ceder ante el "interés objetivo", esto es, la necesidad de salvaguardar los valores y principios constitucionales aunque no se le hubieran denunciado.

La Sala Constitucional del Tribunal Supremo de Justicia venezolano ha indicado sobre el "orden público constitucional" que se trata de un "interés que pertenece al ordenamiento jurídico constitucional, puesto de manifiesto en las normas constitucionales que garantizan la incolumidad del texto fundamental en cuanto a su supremacía normativa, comprendido en los principios, garantías y derechos fundamentales prescritos en la Constitución, porque el estado ha previsto en ésta sus propios fines públicos, es decir, el interés público que lo titulariza, expresado en el interés constitucional que contienen aquellos principios, garantías y derechos fundamentales establecidos en la Constitución de la República Bolivariana 
de Venezuela"87. Esta noción se nos presenta ambigua, amorfa, indeterminada, y débilmente construida por la Sala Constitucional pero que, justifica la intromisión de la Sala ante peticiones no realizadas por los justiciables, o para ir más allá de lo solicitado, o sobre un aspecto diferente de lo solicitado, cuestión que, mirado desde la óptica del procedimiento civil configurarían clarísimos vicios de la sentencia como la ultrapetita o citrapetita. Sin embargo, el "orden público constitucional" se presenta como la caja de pandora que todo explica y todo justifica. Dice la Sala que se trata de un "interés" puesto de manifiesto en las normas constitucionales que garantizan i) la incolumidad del texto constitucional en cuanto a su supremacía normativa; ii) presencia del interés público, y repite circularmente la misma expresión. Reiteramos una cosa es que, el juez constitucional, pueda observar lesiones constitucionales no denunciadas (siempre y cuando ello sea constatable de los "hechos" alegados y probados en el juicio), y otra cosa es querer "cambiar la pretensión" sobre la base del orden público constitucional, salvo claro está que la Ley atribuya competencia para que la Sala pueda actuar de oficio sobre determinadas materias por razones de interés general. Cierto es que, en todos los procedimientos constitucionales, existe una presencia "intensa" del interés público o interés general, pero hay que cuidar los límites y las fronteras, pues no siempre que existe el interés público significa que estamos en presencia del "orden público", aun cuando toda presencia del orden público implica la presencia del “interés público”. Lo que legitima la actuación oficiosa de la Sala, tanto en el ámbito sustantivo como cautelar, es el "orden público", pues el interés público no es suficiente justificación.

\section{Juzgar en Derecho Constitucional}

Tomamos prestada esta expresión de Gustavo Zagrebelsky ${ }^{88}$ para culminar estas nociones introductorias al Derecho Procesal Constitucional que, en nuestro país, no ha tenido en el ámbito de nuestra doctrina mayor trascendencia, y de hecho han sido algunos pocos "constitucionalistas" quienes han dedicado algunos estudios particulares como el maestro Brewer-Carías y algunos trabajos de Carlos Ayala Corao y Jesús María Casal. Sin embargo, la tarea está por hacer, el mandado ya ha sido exigido por nuestro Texto Fundamental. ¿Qué peculiaridades posee el “juicio constitucional" que lo distinguen y diferencian de tarea diaria de los jueces de otras competencias materiales? Mucho se ha criticado a nuestra Sala Constitucional por sus "inventos constitucionalizantes", desde usurpar la función del Parlamento Nacional al "legislar" sobre el procedimiento de amparo, habeas data, procesos

$87 \quad$ Véase Venezuela. Sala Constitucional: Sentencia n ${ }^{\circ} 479$ de 15 de marzo de 2007 (Banco de Venezuela, S.A.C.A. en amparo constitucional contra sentencia del Juzgado Superior del Trabajo del Estado Lara, exp. 06-0341).

88 Vid. ZAGREBELSKY, Gustavo: "Jueces constitucionales", en Revista Iberoamericana de Derecho Procesal Constitucional, n 6, julio-diciembre 2006. Ed. Porrúa, p. 325. 
colectivos, etc., a través de aquella especie de "jurisdicción normativa" que exigió un alarde de imaginación y creatividad. También ha creado normas y ha designado funcionarios que le correspondían al Parlamento bajo la afirmación de una "omisión constitucional", y luego ha extendido la "interpretación constitucional" hacia campos que le pertenecen a otras Salas del mismo TSJ.

Objetivamente, la Sala Constitucional de nuestro Tribunal Supremo de Justicia presenta una gran virtud y una gran debilidad en esta primera década de vigencia: (i) Ha contribuido extraordinariamente en la modulación del Derecho Procesal Constitucional, pues aún sin ley alguna, su jurisprudencia de verdadera creación pretoriana, ha significado claridad en muchas instituciones pendientes pero necesarias; sin embargo, (ii) Su comportamiento revela un sesgo político-partidista de servicio a la "revolución chavista", el partido político del gobierno, y una defensa a ultranza tanto del Presidente de la República como del Ejecutivo, aun con el sacrificio del prestigio bien ganado que tenían algunos de sus magistrados, y lo peor del caso, en detrimento del ansiado "Estado democrático y constitucional" que nuestra Constitución postula. Cuando llegue la hora de resumir, seguramente no habrá forma de llegar a otra conclusión, si realmente se quiere realizar un análisis franco sobre nuestra historia reciente, pues en no pocas ocasiones la Sala Constitucional se ha ganado el mote popular de "Sala inconstitucional", deslegitimada ante el juicio de un amplio sector de la población venezolana, y se ha comportado en una "oficina ministerial" de complacencias políticas. Razones por las cuales los magistrados cuando terminan su mandato son designados embajadores, y en otros cargos de alta confianza presidencial. Más allá de este "accidente histórico" en nuestra vida republicana, la enseñanza que nos debe dejar lo resume magistralmente Néstor Pedro Sagüés cuando comenta que "El auge del Derecho Procesal Constitucional tiene también sus retos, como son el planteamiento de una mejor magistratura constitucional, (en particular, idónea en espíritu constitucional y en Derecho Constitucional, profundamente independiente y equilibrada en sus pronunciamientos, previendo las consecuencias de sus decisiones) y la articulación de procesos constitucionales realmente operativos, lo que significa proveer los medios del caso" ${ }^{\prime 2}$.

Ahora bien, también es impensable un juez aséptico ante la situación social y "Política" del país, y ello es así porque la "substancia" del DPC es la Constitución, y ésta asume el significado de norma constitutiva y reguladora de la vida política asociada, de pacto social, de ley fundamental capaz de conformar la toda vida constitucional. Y como dice Alfonso Celotto, "en esta concepción no puede dejar de emerger inmediatamente la exigencia de un sistema de justicia constitucional, es decir, de un control operado por un órgano independiente de las fuerzas po-

89 Vid. SAGÜÉS, Néstor Pedro: "El desarrollo del Derecho Procesal Constitucional: logros y obstáculos", en Revista Iberoamericana de Derecho Procesal Constitucional, $\mathrm{n}^{\circ} 2$, julio-diciembre 2004. Ed. Porrúa, p. 186; Cfr. OLANO GARCÎA, Hernán: “El Derecho Procesal Constitucional”. Universitas, $\mathrm{n}^{\circ}$ 109, pp. 619-640. Pontificia Universidad Javeriana. Bogotá, 2005, p. 629. 
líticas, llamado a resolver las controversias entre las autoridades supremas de l'ordinamiento $\mathrm{y}$, sobre todo, a revisar que también los poderes ejercitados por las Asambleas parlamentarias -es decir las leyes- se encuentren conformes a la Constitución" 90 .

Para nadie es un secreto - dice Miguel Carbonell- que una de las piezas maestras de cualquier democracia es un sistema judicial capaz de hacer exigible en la práctica el principio de sujeción de las autoridades al orden jurídico. Allí donde no exista un sistema judicial independiente será muy difícil poder mantener que se trata de un Estado en el que los derechos de los ciudadanos están a salvo y donde la división de poderes tiene algún significado más allá de la retórica que suele acompañarlo ${ }^{91}$. Pero nuestro Estado moderno es absolutamente complejo y como nos vuelve a recordar Celotto, en las actuales formas de estado, basadas en el pluralismo interclasista, caracterizado por la presencia de muchas fuerzas, políticas, económicas, culturales, sociales, religiosas, la Constitución es fruto de acuerdos y compromisos dirigidos a dictar un diseño social y político general. Sirve un órgano imparcial para hacerla vivir y respetar, antes que nada por los miembros del poder público. Como claramente ha sido resaltado por Gustavo Zagrebelsky "las opuestas debilidades que caracterizan las fuerzas sociales y políticas en los regímenes pluralistas sostienen a las partes estatales y, estando en equilibrio, consienten la emersión de un papel neutral de defensa de las condiciones de pluralismo, con el fin de la sobrevivencia y de la garantía de cada una de las fuerzas" 92 . De manera que "juzgar en Constitución” es un modo de defender la democracia, y además es colocar un freno al ejercicio del poder por los entes del Estado; defender la Constitución es afincar la tutela de los Derechos fundamentales cuando se vean amenazados o lesionados por el actuar público, y además, juzgar desde la Constitución es constituirse en un medio de "liberación social" y no un obstáculo. Pero "juzgar desde la Constitución” es someterse, en primer lugar, a su supremacía, porque por encima del poder del Tribunal Constitucional o Sala Constitucional está el "poder de la Constitución". Eso significa que requerimos, con urgencia, jueces que juzguen desde el Estado Constitucional y democrático ${ }^{93}$.

90 Vid. CELOTTO, Alfonso: "La justicia constitucional en el mundo: formas y modelos", en Revista Iberoamericana de Derecho Procesal Constitucional, $\mathrm{n}^{\circ}$ 1, enero-junio 2004. Ed. Porrúa, p. 8.

91 CARBONELL, Miguel: "Los guardianes de las promesas. Poder Judicial y democracia en México", en Revista Iberoamericana de Derecho Procesal Constitucional, n 2 , julio-diciembre 2004. Ed. Porrúa, p. 27.

92 Op. cit., in locus cit.

93 ANDRÉS IBÁÑEZ, Perfecto: "Poder judicial y juez en el Estado constitucional. El sistema de consejo", en La experiencia jurisdiccional: del Estado legislativo al Estado constitucional de derecho. CGPJ. Madrid, 1999; y del mismo autor "Democracia con jueces", Claves de razón práctica, $\mathrm{n}^{\circ}$ 128, diciembre de 2002. Madrid. 
No es comprensible la supuesta interpretación de la Constitución para minimizar los propios intereses constitucionales ${ }^{94}$, como ocurrió con la negativa de la Sala de reconocer la protección a la paternidad por nacimiento de hijo, o la aprobación de la reversión de competencias para favorecer el centralismo del Ejecutivo, la consideración sostenida por la Sala Constitucional de que las Ordenanzas Municipales eran "actos administrativos", la permisividad de la inhabilitación política por el "deseo" del Contralor General de la República, la intervención y el control de empresas privadas a modo de expropiación, entre muchos otros lamentables ejemplos. Requerimos de jueces constitucionales con "virtudes" ${ }^{95}$ y no que se muevan por el "dedo presidencial", jueces formados para la democracia, inquietos intelectualmente, en fin un catálogo amplio de reformas mínimas sobre lo que el Derecho comparado ya se ha pronunciado. Sin duda al juez constitucional debe reconocérseles amplias "potestades" para actuar de oficio (y no la cacareada "discrecionalidad" que ha postulado la Sala en relación con los procedimientos constitucionales), una previsión amplia de un poder cautelar e incluso de tutela anticipada, que sirvan de palanca en la finalidad concreta del Derecho Procesal Constitucional: un servicio de justicia a la Constitución y a la Democracia. Razón tiene Humberto Nogueira cuando define al Tribunal Constitucional de la siguiente manera:

\begin{abstract}
Podemos conceptualizar los Tribunales Constitucionales como órganos supremos constitucionales de única instancia, de carácter permanente, independientes e imparciales, que tienen por función esencial y exclusiva la interpretación y defensa jurisdiccional de la Constitución, a través de procedimientos contenciosos constitucionales referentes como núcleo esencial a la constitucionalidad de normas infra constitucionales y la distribución vertical y horizontal del poder estatal, agregándose generalmente la protección extraordinaria de los derechos fundamentales, que actúan en base a razonamientos jurídicos y cuyas sentencias tienen valor de cosa juzgada, pudiendo expulsar del ordenamiento jurídico las normas consideradas inconstitucionales ${ }^{96}$.
\end{abstract}

Nuestro Derecho Procesal Constitucional está dando sus primeros pasos, y aunque hayamos comenzado con mal pie, siempre hay calma después de la tormenta, y poco a poco toda noche va empujando al sol.

94 ASIS, Rafael de: Jueces y normas. La decisión judicial desde el ordenamiento (prólogo de Gregorio Peces Barba). Ed. Marcial Pons. Madrid, 1995.

95 ATIENZA, Manuel: "Virtudes judiciales. Selección y formación de los jueces en el Estado de derecho", en CARBONELL, Miguel et. al. (Comp.): Jueces y derecho. Problemas contemporáneos. Universidad Nacional Autónoma de México, 2004. Ed. Porrúa. Cfr. BUSCAGLIA, Edgardo: “Los principales obstáculos de la reforma judicial en América Latina”, en JARQUIN, Edmundo y CARRILLO, Fernando (eds.): La economía política de la reforma judicial. Banco Interamericano de Desarrollo. Washington, 1997.

96 Vid. NOGUEIRA ALCALA, Humberto: "La independencia y responsabilidad del juez constitucional en el derecho constitucional comparado", en Revista Iberoamericana de Derecho Procesal Constitucional, n 1, enero-junio. Ed. Porrúa, 2004, p. 61 y ss. 
